\title{
Religião e gênero em espaços plurais
}

\section{Masculinidades na prisão através das vivências de sujeitos evangélicos}

\author{
Masculinities in prison through the experiences of evangelical individuals
}

\author{
Ana Beatriz Vilhena ${ }^{1}$ \\ abeatriz.vilhena@gmail.com
}

\begin{abstract}
Resumo: Escritos que tangenciam religião e prisão, população LGBTQI+, sexualidade das mulheres encarceradas, trajetórias dos "criminosos" têm, nos últimos anos, suscitado a curiosidade da sociedade civil, bem como da academia. Se, nessa mesma sociedade, os homens enquanto identidade de gênero são detentores de toda a sorte de privilégios, no que tange à população carcerária masculina, são invisibilizados. O presente artigo propõe um estudo sobre as dinâmicas de produção das masculinidades em contexto prisional, tendo como elemento fundamental as religiosidades evangélicas. Dessa forma, entendemos ser possível compreender a produção das masculinidades a partir de repertório evangélico e as implicações desses processos em um cenário mais amplo.
\end{abstract}

Palavras-chave: Masculinidades. Prisão. Religiosidades evangélicas. Dispositivo da sexualidade. Homohisteria.

\begin{abstract}
Writings that relate religion and prison, LGBTQI+ population, women's sexuality in jail, the life stories of the offenders, all have been raising the curiosity from the civil society and also from academics. While in this same society, men hold all kinds of privileges, when it comes down to prison male population, these men are invisible. For that matter, the present article proposes a study about the dynamical production of masculinities in prison, having as a central element the evangelical religiosities. In this sense, we understand that we can comprehend the production of these masculinities having the evangelical religiosities as a main resource and their implications in a broader scenario.
\end{abstract}

Key-words: Masculinities. Prison. Evangelical religiosities. Sexuality device. Homohistery.

\section{Introdução}

As pesquisas sobre religião e sistema prisional tiveram um ápice de publicações no final da década de 1990 até meados de 2000. Após esse período, a temática parou de receber

\footnotetext{
${ }^{1}$ Mestra e Doutoranda em Ciência da Religião pela Universidade Federal de Juiz de Fora. Integrante do grupo de pesquisas em Religião, Educação e Gênero do Programa de Pós-graduação em Ciência da Religião da UFJF (REDUGE - PPCIR/ UFJF).
} 
tratamento sistemático. Em contrapartida, o significativo crescimento da população carcerária feminina brasileira parece ter suscitado o interesse de pesquisadores pelas questões de gênero, com enfoque nas mulheres e na comunidade LGBTTQI+ em contexto de privação de liberdade.

Pesquisas sobre a sexualidade das mulheres em situação de cárcere e das comunidades LGBTTQI, maternidade na prisão, alas para travestis e abuso de autoridade policial contra essas minorias bem como as relações sociais desses grupos na prisão têm se multiplicado (BOLDRIN, 2015; PADOVANI, 2015; ZAMBONI, 2016). Porém, nos parece que existe uma lacuna principalmente nas pesquisas brasileiras.

De acordo com o World Prison Brief ${ }^{2}$ de 2016, a população carcerária mundial é composta de mais de $90 \%$ de homens, apesar do crescimento do encarceramento feminino. No Brasil, os números também são extensos. Segundo o INFOPEN $^{3}$, também de 2016, a população carcerária masculina brasileira ultrapassa o montante de 660.000 , para pouco mais de 42.000 mulheres. Por que os homens são a maioria da população carcerária mundial?

Apesar dos homens serem detentores de diversos privilégios em relação às mulheres, inclusive no quesito visibilidade, no que tange pesquisas em criminalidade no Brasil eles se tornam invisíveis ${ }^{4}$. Tais questões nos levaram a buscar conceitos e metodologias para o desenvolvimento de uma análise sobre a produção das masculinidades na prisão tendo como elemento fundamental a religiosidade evangélica.

Nesse sentido, o presente ensaio é baseado na dissertação intitulada "São os evangélicos que seguram essa cadeia, se não fosse eles, quem iria converter os mauzão?”: considerações sobre o papel do proceder evangélico na prisão (VILHENA, 2017) ${ }^{5}$, que fornece dados sobre as religiosidades evangélicas da prisão pesquisada.

A partir do diário de campo obtido com essa pesquisa, fizemos o recorte de dois episódios para a análise das masculinidades evangélicas na prisão utilizando os conceitos de

\footnotetext{
${ }^{2}$ Instituição inglesa que compila informações sobre as prisões de todos os países independentes. O objetivo é produzir e disseminar conhecimento sobre o sistema e promover melhorias. Disponível em: http://www.prisonstudies.org/. Acesso em: Agosto de 2018.

${ }^{3}$ Levantamento Nacional de Informações Penitenciárias. Disponível em: http://dados.gov.br/dataset/infopenlevantamento-nacional-de-informacoes-penitenciarias1. Acesso em: Agosto de 2018.

${ }^{4}$ Os estudos em criminologia na Inglaterra se debruçam há décadas sobre a relação entre masculinidades e prisão. O exemplo mais atual da produção sobre o tema foi condensado no livro New Perspectives on Prison Masculinities (2018). Os artigos que compõem a obra analisam os diversos aspectos relacionais das masculinidades em ambiente prisional.

${ }^{5} \mathrm{O}$ "proceder evangélico"consiste em um código ético e moral seguido apenas por detentos evangélicos e se difere do código de condutas da massa carcerária em geral, denominado apenas "proceder" (Marques, 2009). O trabalho de campo envolveu observação participante nos cultos e pregações de cela em cela e entrevistas com detentos e funcionários.
} 
dispositivo da sexualidade, homohisteria e masculinidades hegemônicas. O primeiro episódio ocorreu durante um evento religioso, realizado por uma igreja neopentecostal da cidade, cujo pastor é ex-integrante da vida no crime, porém, nunca preso.

Estavam presentes no culto aproximadamente cinco pastores, um pesquisador também da Ciência da Religião, a pesquisadora e cerca de vinte detentos. O primeiro episódio a ser analisado ocorreu quando o grupo retornava à cela onde ocorria a pregação. O pastor líder, exintegrante da criminalidade, pede ao pesquisador homem que avisasse à pesquisadora mulher para aguardar ao lado de fora por alguns momentos, pois iria pregar sobre assuntos que poderiam constranger, por ser a única mulher.

Aguardando em uma sala próxima, foi possível ouvir a pregação e observar por entre as frestas da parede que separava a presença na cela. O pastor, então, pede que os detentos coloquem as mãos em suas genitálias, por dentro da calça, e começa a pregar para "repreender os desejos homossexuais, os desejos da carne".

O segundo episódio a ser analisado ocorreu durante uma conversa com um detento religioso sobre o "proceder evangélico". Durante sua fala, o homem afirma que "ninguém quer veado na cela, pega mal”. Tais episódios suscitaram diversas questões sobre gênero, sexualidade e religiosidades dos homens nesse contexto, que serão investigadas neste ensaio.

As conclusões parciais indicam diferenças entre a realização das masculinidades evangélicas e as masculinidades não religiosas. Indicam, também, que a produção das identidades generificadas evangélicas têm na corporeidade e no corpo um elemento chave para se realizar.

\section{Feminismo e masculinidades}

O uso da categoria de análise gênero para os estudos das diferenças sexuais partiu da iniciativa feminista. O movimento de libertação das mulheres e as múltiplas pesquisas que buscavam compreender as relações de gênero colocando o homem como objeto central, gerou reação dos homens fazendo com que surgissem teorias diversas. Essas pesquisas falhavam em uma teorização aprofundada sobre as relações de gênero, algumas chegando a culpabilizar as mulheres.

Uma das teorias criadas no calor dessas discussões foi a teoria dos papéis sociais. Os autores dessa vertente preconizavam as interações a nível individual em detrimento das estruturas sociais, ou seja, para eles as relações se davam em termos de papéis a serem cumpridos, entre homens e mulheres de forma a se complementarem. 
A partir dessa abordagem desconsideravam que a organização social por critérios de diferenciação não abrangia apenas gênero, mas classe, raça, regionalidade e todos os outros marcadores identitários que diferem de sociedade para sociedade. Além disso, tal interpretação negligencia o fato de que os significados atribuídos à feminilidade e a masculinidade variam de sociedade para sociedade através do tempo histórico.

Como reação a essa teoria surgem formulações sobre gênero, mais especificamente, masculinidades através de perspectiva pós-estruturalista. Robert (hoje Raewyn) Connel, produziu o livro Masculinities (1995) e formulou o conceito de masculinidades hegemônicas utilizado pela maioria dos pesquisadores que abordam a temática, seja para corroborar seja para criticar, mas sempre apontando sua relevância.

Para Connel, as masculinidades hegemônicas são, até aonde podemos ampliar o conceito

[...] simultaneamente um lugar nas relações de gênero, a prática através das quais homens e mulheres comprometem-se com este lugar no gênero e os efeitos destas práticas nas experiências corporificadas, na personalidade e na cultura ${ }^{6}$ (CONNELL, 1995, p. 71).

Hegemonia para ele toma o sentido gramsciano das análises das relações de classe na medida em que se referem à dinâmica cultural através das quais determinados grupos reivindicam e sustentam posição de liderança na vida em sociedade. Para o autor, a masculinidade hegemônica não é um tipo de identidade fixa sempre e em qualquer lugar a mesma.

É um modelo de "homem ideal" ou "homem de verdade" que requer, necessariamente, autoridade, dinheiro, poder, autonomia, visibilidade, e a contraposição ao elemento feminino tornando-os mais próximos da hegemonia. $\mathrm{O}$ autor propõe que as relações que legitimam a centralidade de um tipo de masculinidade em detrimento de outra se exercem nas práticas e mentalidades de: subordinação, marginalização, protesto e cumplicidade.

A subordinação refere-se a relações generificadas de dominação entre homens. Por exemplo, do ponto de vista da masculinidade hegemônica de determinada sociedade e a depender do contexto, ser gay é assimilado com feminilidade e, nesse sentido deve ser é subordinado. A marginalização está relacionada com autorização da classe ou grupo

\footnotetext{
6'Masculinity', to the extent the term can be briefly defined at all, is simultaneously a place in gender relations, the practices through which men and women engage that place in gender, and the effects of these practices in bodily experience, personality and culture(CONNEL, 1995, p.71).
} 
dominante. Podem se exercer na relação do gênero com a classe ou raça. Autor cita como exemplo as masculinidades negras dos atletas americanos.

Esses homens possuem fama, riqueza e prestígio - "autorizados” pela masculinidade hegemônica - porém, a imaginação sobre os homens negros em geral é de pobreza e criminalidade, interpretando papéis simbólicos significativos na realização das masculinidades brancas (1995, p.80). Então, estão em relação de subordinação. A masculinidade de protesto seria realizada especificamente entre homens e meninos em situação de posição social marginalizada e periférica.

Assim como todos os homens, estes também buscam o exercício de poder e a afirmação do controle de suas vidas. Porém, sua posição é contraditória em relação à realidade econômica e social em que vivem o que pode fazer com que realizem masculinidades de forma agressiva, misógina e muitas vezes criminosas. A relação de cumplicidade com o projeto hegemônico faz com que homens adotem a cumplicidade masculina a partir de um dividendo patriarcal. Ou seja, homens que adotam essa cumplicidade não necessariamente realizam masculinidade hegemônica, mas usufruem dos benefícios do

patriarcado. É, principalmente, nesses grupos em que a hegemonia se mostra mais eficaz.

Se, para a realização de identidades masculinas, os homens precisam, necessariamente de elementos como autonomia, dinheiro, controle, poder, vida sexual ativa e contraposição ao feminino, como pensar as masculinidades na prisão, que consiste em um ambiente que inviabiliza esses elementos? Quais os recursos que os presos utilizam para a produção das masculinidades?

\subsection{Masculinidades aprisionadas}

A prisão e suas tecnologias de controle, segundo Foucault, possuem um cinismo nas formas as quais exercem o poder, de maneira arcaica e é "o único lugar onde o poder pode se manifestar em estado puro em suas dimensões mais excessivas e se justificar como poder moral. "Tenho razão em punir pois vocês sabem que é desonesto roubar, matar..." (1978, p. $43)$.

A prisão moderna foi pensada com intuito da transformação e reabilitação dos indivíduos. Esse projeto falhou desde seu surgimento, pois, em vez de ressocializar, passou a fabricar ou reproduzir a delinquência e o delinquente. Estrategicamente, a função da prisão e dos criminosos foi modificada: os delinquentes produzidos, agora, serviriam como meio de legitimar os aparatos institucionais do Estado e, dessa forma, seu poder. 
O principal objetivo do dispositivo prisional ultrapassa punição física: ele classifica, segrega, controla e vigia não só o corpo do apenado, mas também suas identidades subjetivas por meio de uma disciplina que produz um "ser preso".

Cadeia? Guarda o que o sistema não quis. Esconde o que a novela não diz. Cada sentença [...] uma história de lágrima, sangue, vidas e glórias, abandono, miséria, ódio, sofrimento, desprezo, desilusão, ação do tempo. Misture bem essa química. Pronto. Eis um novo detento”. (Racionais Mcs, Diário de um detento, 1997).

A estrofe da música citada acima ilustra os processos pelos quais, segundo Goffman (1961, p.24), o sujeito passa no cotidiano da prisão: humilhação, degradação e mortificação do eu. Esses processos realocam as identidades individuais e: pronto "eis um novo detento" e não mais um sujeito de direitos e deveres.

Podemos dizer que o sujeito sofre uma morte social e passa a se situar em um mundo paralelo. Não está nem dentro, nem fora da prisão, mas vive "dentro da própria mente"7, negociando e renegociando sua sobrevivência nas interações e práticas cotidianas, aonde os únicos repertórios disponíveis são a agressividade, medo e violência. $\mathrm{O}$ crime é essencializado e, dessa forma, o sujeito criminoso é constantemente produzido e reproduzido através de normas exatamente opostas às que os cidadãos de "bem" são produzidos.

Johnny Cash, conhecido como "embaixador dos presos", no encarte de um de seus CD's, exemplifica o impacto do aprisionamento nas identidades masculinas: "Todos vocês tiveram as mesmas coisas aniquiladas de suas vidas, tudo que parece fazer de um homem, um homem - mulheres, dinheiro, uma família, um trabalho, a estrada aberta, a cidade, o campo, ambição, poder, sucesso, falhas - um milhão de coisas" 8 .

Na medida em que relacionamentos heterossexuais são exíguos na prisão e que, esses homens vivem numa extrema proximidade física, o ambiente do cárcere parece demandar dos homens que demonstrem ou provem suas identidades masculinas de formas ainda mais agressivas e homofóbicas para evitar serem associados com a homossexualidade.

Para Sloan (2011), ao adentrar a prisão, os homens passam a sofrer processos de feminilização na medida em que são controlados, perdem a autonomia, liberdade, dinheiro, poder e se tornam invisíveis. Esses processos podem gerar como reação, ainda segundo a

\footnotetext{
${ }^{7}$ Diário de Campo, 2015.

8“All of you have the same things snuffed out of your lives, everything it seems that makes a man a man women, money, a family, a job, the open road, the city, the country, ambition, power, success, failure - a million things" (CASH, 2006).
} 
autora, identidades hipermasculinas que são realizadas de forma agressiva, misógina ou homofóbica, no intuito de não serem homossexualizados, ou feminilizados.

Esse medo de ser homossexualizado foi conceitualizado por Anderson (2009) como homohisteria. A homohisteria consiste em medo coletivo e individual dos homens de serem homossexualizados, gerando a suspeição de que a homossexualidade está próxima e que deve ser evitada e combatida. A cultura de homohisteria tem como seu motor a necessidade de conscientização pública e em massa de que as pessoas "normais" também poderiam ser homossexuais.

Entendemos através das formulações de Foucault que a homohisteria consiste em um dispositivs de sexualidade que pode ser acionado pela religiosidade evangélica no cárcere. Para o autor os dispositivos estão sempre inscritos em jogos de poder que mudam posições, funções e estratégias a depender da necessidade do contexto. A sexualidade, então

\begin{abstract}
está ligada a dispositivos recentes de poder; esteve em expansão crescente a partir do século XVII; 3) a articulação que a tem sustentado, desde então, não se ordena em função da reprodução; esta articulação, desde a origem, vinculou-se a uma intensificação do corpo, à sua valorização como objeto de saber e como elemento nas relações de poder (Foucault, 2014, p. 100-101.).
\end{abstract}

Essa noção coaduna com a formulação de homohisteria de Anderson (2009) na medida em que 1) não está individualmente localizada, mas paira no ambiente como uma rede que articula as relações de poder e guia a mentalidade que gera as práticas hipermasculinas na prisão; 2) é historicamente localizada e pode ser ressignificada a depender da necessidade estratégica e 3)Enquanto dispositivo da sexualidade promove "[...] a incitação ao discurso, a formação dos conhecimentos, o reforço dos controles e das resistências[...]" (Foucault, 2014, p. 99).

\title{
1.2 Masculinidades evangélicas na prisão: analisando os dados
}

Durante a realização da dissertação constatamos que as denominações institucionais das religiões pentecostais na prisão são pouco relevantes para os detentos adeptos do "proceder evangélico". Na dinâmica religiosa desse contexto, os adeptos fazem uso de elementos que circulam através dos repertórios evangélicos de diversas denominações ${ }^{9}$ de acordo com o que lhes convém.

\footnotetext{
9 À época da etnografia (2015), constavam doze igrejas credenciadas para fornecer assistência religiosa, sendo onze evangélicas pentecostais e neopentecostais e a Igreja Católica.
} 
Esse repertório tem como base "a ênfase na cura, no louvor musical e na emoção e a cópia de práticas e estratégias proselitistas bem-sucedidas" (MARIANO, 2011, p. 30), como percebido em campo. Unificou-se, ali, um ser "evangélico" em contraposição aos dogmas católicos e, claro, às religiões de matriz africana.

Até aqui entendemos que as masculinidades consideradas legítimas necessitam de recursos como: autonomia, força, controle, habilidade e poder para serem exercidas e, principalmente, precisa se contrapor ao que atribuído ao reino feminino, como: debilidade, fragilidade subserviência, falta de autonomia, de controle dentre outros.

A partir disso surge um contraponto.

As identidades masculinas produzidas através do repertorio religioso se dão através da renúncia da autonomia, do controle de suas vidas, devoção e a submissão de seus corpos e espíritos a Deus. Figura esta que representa um Deus experienciado, sentido, entendido e imaginado como masculino.

A ideia de uma relação homoerótica entre a figura imaginada de Deus e seus crentes que se identificam com o gênero masculino não é exatamente nova. Eilberg-Schwartz (1995) questiona como a imagem incorpórea de um Deus pai surgiu. Sua hipótese é a de que o próprio desconforto da ideia de uma relação dos homens com uma figura que tenha um pênis tenha gerado a mentalidade vigente até a contemporaneidade: a de um Deus desencarnado. Esse Deus cristão, figura imaginada como masculina é incorpórea, logo, não tem sexo.

Neste ponto, é que confrontamos a teoria de Sloan (2011) que afirma que os homens sofrem processos feminilizadores ao adentrarem a prisão. Na medida em que Os evangélicos optam e, mais do que isso, desejam esse processo que a autora chamou de feminilização com a figura masculina do Deus cristão. Retomando os dados etnográficos a partir do enquadramento teórico aqui exposto é possível fazer algumas inferências.

Sobre o episódio um, quando o pastor pede para que os detentos coloquem as mãos nas genitais para repreender desejos homossexuais, se analisarmos por perspectiva foucaultiana, é possível afirmar que, se houve tal repreensão é por que tais desejos e práticas já existem entre os evangélicos. Logo, o corpo e as relações sexuais entre os homens possuem

O segundo episódio sobre a fala "Ninguém quer veado na cela, pega mal" pode corroborar a percepção que o coletivo tem da homossexualidade e evidencia o medo de serem homossexualizados. Coletivo, na medida em que, "ninguém" quer compartilhar a cela com “veados", pois não é bem visto, tanto pelos adeptos do "proceder evangélico", quanto para os adeptos do proceder. 
Através dessas situações, também se torna possível afirmar que a mentalidade de homohisteria na prisão é gerada através de repertórios e vocabulários religiosos de tradição judaico-cristãos e, no contexto da prisão pesquisada, alimentada por elementos teológicos (neo) pentecostais.

\section{Conclusões parciais}

Os dados etnográficos que embasaram o primeiro momento da pesquisa analisados pelo enquadramento teórico aqui delineado nos indicaram questões iniciais relevantes. As masculinidades podem ser percebidas em textos bíblicos, como analisado por EilbergSchwartz (1995).

A partir disso, as interpretações posteriores foram, pouco a pouco, moldando as mentalidades e as estruturas sociais que possuímos até os dias atuais. Estruturas estas que foram pensadas, idealizadas e criadas por homens (no sentido pleno da palavra em cada contexto histórico que se passou até hoje) para homens.

Logo, essas considerações iniciais sobre a homohisteria enquanto dispositivo de sexualidade acionado pelo repertório evangélico na prisão, a corporeidade enquanto elemento chave na realização das masculinidades evangélicas serão suporte teórico para as questões a serem investigadas com a volta ao campo.

\section{Referências}

ANDERSON, E. Inclusive masculinity: The changing nature of masculinities.

London: Routledge, 2009.

Connell, R. W (1995). Masculinities. Berkeley: University of California Press.

FOUCAULT, Michel. Vigiar e punir: história da violência nas prisões. 12. Ed.

Petrópolis: Vozes, 1975.

GOFFMAN, Erving. Estigma: notas sobre a manipulação da identidade deteriorada. 4. Ed. Rio de Janeiro: LTC, 1988.

Coleção debates.

Manicômios, prisões e conventos. São Paulo: Perspectiva, 1974.

MARIANO, Ricardo. Sociologia do crescimento Petentecostal no Brasil: um balanço.

Perspectiva Teológica, Belo Horizonte, Ano 43, Número 119, p. 11-36, Jan/Abr, 2011.

MARQUES, Adalton. Crime, proceder, convívio - seguro: um experimento antropológico a partir de relações entre ladrões. 2009. 119f. Dissertação (Mestrado em Antropologia Social). Universidade de São Paulo, São Paulo, 2009.

MEDRADO, Benedito; LYRA, Jorge. Por uma matriz feminista de gênero para os estudos sobre homens e masculinidades. Disponível em: http://www.scielo.br/pdf/ref/v16n3/05.pdf. Acesso em: 20/10/2018. 
RODRIGUES, Elisa. A mão de Deus está aqui!: estudo etnográfico da Igreja Mundial do Poder de Deus. 2014. 340 p. Tese (doutorado) - Universidade Estadual de Campinas, Instituto de Filosofia e Ciências Humanas, Campinas, 2014.

SCOTT, Joan. Gênero: uma categoria útil para a análise histórica. Disponível em:

http://disciplinas.stoa.usp.br/pluginfile.php/6393/mod_resource/content $/ 1 / \mathrm{G} \% \mathrm{C} 3 \% \mathrm{AAn}$ ero-Joan\%20Scott.pdf. Acesso em: 18/10/2018.

SLOAN, J. Men inside: Masculinity and the adult male prison experience. Unpublished $\mathrm{PhD}$ thesis, The University of Sheffield. 2011.

Vilhena Pereira, Ana Beatriz de. São os evangélicos que seguram essa cadeia, se não fossem eles, quem iria converter os mauzão? : considerações sobre o papel do "proceder evangélico" na prisão / Ana Beatriz de Vilhena Pereira. 2017. 99 f. 


\title{
Mulher e folia: deslocamentos possíveis, caminhos renovados
}

\author{
Woman and Revelry: possible displacements, renewed paths
}

\author{
Andiara Barbosa Neder ${ }^{10}$ \\ andiaraneder@yahoo.com.br
}

\begin{abstract}
Resumo: Apesar das pessoas envolvidas nas Folias de Reis gostarem de afirmar uma imutabilidade dos rituais e uma "firmeza" das tradições como uma virtude de seu grupo, é possível perceber que muitos elementos foram alterados, o que na verdade intensifica a ideia de cultura viva e em constante renovação. São exatamente essas pequenas desconstruções, reconstruções e ressignificações que são salientadas neste estudo, atentando principalmente para os deslocamentos em torno das proibições e obrigações referentes à questão de gênero. É necessário observar em que aspectos a mulher assume papel de liderança e como isto se deu, e por outro lado, quando a ela ainda se destina a marginalidade, seja organizacional, ritual ou dos saberes.
\end{abstract}

Palavras- chave: Folia de Reis; mulher; deslocamentos

Abstract: Although people involved in Revelry of Kings like to affirm an immutability of rituals and a "firmness" of traditions as a virtue of their group, it is possible to perceive that many elements have been altered, which in fact intensifies the idea of living culture and in constant renewal. It is precisely these small deconstructions, reconstructions and resignifications that are emphasized in this study, because different actions can wave different actors and especially a different construction of thought. This communication is concerned with highlighting the changes that occurred and the reason for such changes. Focused mainly on the deconstructions around the prohibitions and obligations regarding the gender issue. It is necessary to observe in which aspects the woman assumes a leadership role and how this happened, and, on the other hand, when she is still destined for marginality, whether it is organizational, ritual or of knowledge.

Keywords: Revelry of Kings; woman; displacements.

\section{As mulheres à frente}

Para analisar as diferenças entre a Folia de Reis do presente e do passado é necessário traçar primeiramente uma análise dos elementos facilitadores da organização dos giros e também os percalços e entreves enfrentados pelos grupos na atualidade. Muitos obstáculos do passado foram elementos impulsionadores de mudanças atuais. Assim como os obstáculos de hoje podem ser superados no do futuro através de uma dinâmica de adaptação que passa obrigatoriamente por alterações, pequenas ou amplas, estruturais ou pontuais. A partir daí, é

\footnotetext{
${ }^{10}$ Mestra e doutoranda em Ciência da Religião pelo Programa de Pós-graduação em Ciência da Religião da Universidade Federal de Juiz de Fora.
} 
possível entender o papel da mulher nesse contexto mutante e sua importância para a promoção da festa e continuidade da tradição.

No setor dos serviços, ou seja, nas funções dos bastidores invisibilizadas, mas desuma importância para a promoção da festa, são perceptíveis os deslocamentos ocorridos no que tange à questão de gênero. Se no passado, às mulheres caberia apenas funções de menor hierarquia no setor dos serviços, hoje elas já se inserem em todos os setores da festa. No próprio setor dos serviços, elas atuam inclusive nas funções burocráticas e administrativas. Se antigos serviços dentro da folia eram considerados como obrigação da mulher, hoje se reconhece a importância e centralidade de alguns serviços por elas prestados. Uma prova disso é o reconhecimento por parte dos foliões dessas funções, incluindo um agradecimento especial em sua cantoria às cozinheiras em alguns grupos. Outro exemplo é uma função específica de mulheres dentro da folia, o cargo de Madrinha da Bandeira, citado por Maú em entrevista. É uma espécie de zeladora da bandeira. Na casa da Madrinha a bandeira fica guardada durante o ano todo sob os seus cuidados, recebendo manutenção, sendo revitalizada quando necessário, retiradas as fitas e enfeites velhos e mantendo o objeto pronto para sair no próximo giro. Se determinada função recebe um nome, então é porque ela não é tão invisibilizada assim. Ela tem uma importância para o grupo. Então é possível perceber que nesse momento é notada a contribuição feminina em serviços para a folia. Maú afirma:

\footnotetext{
Maú: Eu era Madrinha da fulia e Banderera da fulia.

ABN: Que que é a Madrinha?

Maú: A Madrinha é assim, quando que a bandera tá na sua casa, aí invés deles falá assim, cê é a dona da fulia, não, cê é a Madrinha da Bandera. [...] Eu era a Madrinha porque eu arrumava a bandera.

Zezé: Cê sempre foi Madrinha da Bandera! Ela sempre foi Madrinha da Bandera! Dexa eu explicá! Sabe por quê? Porque ela sempre feiz a montagem da bandera, entendeu? [...] ela sempre foi a da frente! 'Ah a minha bandera eu quero desse jeito e tal! 11
}

Sobretudo importa salientar que o cargo não é reconhecido em todas as folias, apesar da função já ser realizada pelas mulheres há pelo menos dois séculos em Leopoldina. As entrevistadas da Serra dos Barbosas não reconhecem o nome da função que executam há tanto tempo. Como uma herança que a mãe deixa para a filha, Cássia realiza tal serviço como uma extensão de seus afazeres diários e sem questionar se seria uma função de fato sua. Como sua mãe já fazia para a folia ela continua fazendo. E não é um trabalho fácil ou rápido, apesar da prática já tê-la ensinado atalhos que agilizam tal processo. Se na Serra ainda não enxergam a

\footnotetext{
${ }^{11}$ Entrevista com Maú em sua residência, dia 7 de setembro de 2017.
} 
atuação da Madrinha da Bandeira como uma função digna de lembrança e gratidão, pois nem nomeada é, isso se dá pela total invisibilidade da função feminina, pois o objeto em si é o de maior importância ritual, objeto sagrado, representante do poder taumaturgo dos Santos Reis e símbolo da credibilidade da folia. Algo sempre feito e nunca questionado torna-se uma obrigação tão naturalizada que parece uma função inata de seus agentes, no caso, as mulheres. E se não é mais do que sua obrigação, não há necessidade de se tornar visível ou agradecer. Por outro lado duas mulheres da comunidade já foram homenageadas pela Folia da Serra. Uma se mostrou importante por lavar e passar as roupas dos foliões e a outra por dar almoço a todas as folias que levam a Benção da Bandeira em sua residência. Cássia lembra:

\footnotetext{
Cássia:Ela tinha o compromisso de lavá e passá! Ela acompanhava a noite toda, aí ás vezes, vinha durmi ali na casa da cunhada dela ali, 'Ai! Tenho qui lavá ropa!' 'Leula, vai durmi! Qui amanhã lava ropa!' 'Pó dexá, pó dexá, qui prá passá eu vô te chamá!' (risos)[...] Ela tinha esse comprimisso! Ficô muitos anos cum esse compromisso, sabe?! [...] Enquanto num lavava a ropa... tem que lavá a ropa prá i durmi, sabe?![...] Ela até recebeu, foi homenageada, coitada! [...] Foi homenageada lá no CAC em janero, quando foi outubro ela morreu. [...] Ela recebeu por esse mérito de cuidá dos uniforme dos foliões, a Dona Zezé recebeu tamém, homenageada lá, também por dá almoço todas as fulia, sabe?!

$[\ldots]$

ABN: Então antigamente não tinha esse reconhecimento pelas mulheres, não? Cida: Nãaaao... tinha nada... ${ }^{12}$
}

Porém é importante ressaltar que a contribuição é notada e bem aceita quando a atuação da mulher é no setor dos serviços e nas funções que tradicionalmente já lhe são atribuídas. A diferença é que no passado todas as funções tradicionalmente desenvolvidas por elas não eram sequer notadas como contribuições voluntárias, mas tinham o peso de uma obrigação, como ainda é a função de Madrinha da Bandeira em muitos grupos. E por mais que hoje já se reconheça o caráter voluntário e colaborativo de certas ações, algumas mulheres, como Cida com o cuidados da bandeira, Leula com as roupas e Dona Zezé com a comida, interiorizaram como obrigação. Pode-se perceber isso pelo tom de pesar com que Leula asseverava que iria lavar roupa de madrugada, antes mesmo de dormir. Como quem admite que a obrigação vem antes do descanso. Se atualmente são homenageadas por exercer tais funções, é devido a uma percepção recente de que não é uma obrigação e sim uma contribuição à folia. A gratidão do grupo em relação à sua contribuição é como um título de confiança oferecido à mulher que atua nos bastidores da festa, como um incentivo para que dali ela não saia. Um título que, mais aprisiona do que liberta, mais solidifica a permanência do que afirma a mudança, mais reproduz os comportamentos e atitudes imputados às

\footnotetext{
${ }^{12}$ Entrevista realizada com Cássia, em sua residência, no dia 10 de outubro de 2017.
} 
mulheres do que desarticula as "verdades" cristalizadas. Embora não tenha sido essa uma intenção consciente de quem teve a ideia de reconhecer o trabalho dessas mulheres em forma de homenagem, nesse cenário onde não há um movimento feminino organizado que incite reflexões e possibilite deslocamentos, tal homenagem, apesar apontar uma mudança de percepção, não permite uma mudança de atitude. Pois encerra a mulher ainda mais na inércia, quando valoriza essas atividades que elas fazem, que suas mães fizeram, que suas avós fizeram... e que suas filhas farão se o ciclo não for rompido. Claro que os serviços devem ser feitos, pois sem eles os giros não são possíveis. Mas que não sejam elas as únicas responsáveis por eles.

É notável que em muitos grupos as mulheres passaram a assumir cargos de liderança por elas nunca antes alcançados. Por outro lado os homens não se veem impelidos ou motivados a fazer os serviços antes destinados apenas às mulheres, salvas raras exceções. Dessa forma, elas assumem tanto as funções que antes lhes eram impelidas, quanto a de chefia que conquistaram.

Enquanto donas de folias, cargo de liderança e de grande responsabilidade, as mulheres hoje assumem mais demandas que no passado. E se comparada com a direção masculina da atualidade, se percebem diferenças marcantes entre os dois tipos de gestão. Os homens que assumem tal função lidam somente com questões estritamente administrativas, burocráticas e de tesouraria quando o grupo não tem um tesoureiro responsável, e direcionam os afazeres necessários a outros e muitas vezes outras colaboradoras. Já as mulheres assumem a direção de forma holística e dificilmente delega a terceiros as funções que ela mesma pode ou já está acostumada a fazer.

As mulheres assumem todas as esferas da administração, resolvendo desde as questões burocráticas até as questões de organização das festas. Atualmente as questões burocráticas são demandas reais, que antigamente não se impunham às folias urbanas e menos ainda às rurais. A licença liberada pela delegacia não era necessária para respaldar os giros diante das autoridades. O registro em cartório, que iniciou um processo de nomeação oficial dos grupos, sempre referendados pelos nomes dos donos (mesmo depois da criação do registro), segundo Maú começou a ser feito pela existência de uma verba municipal destinada à cultura. Para que a verba fosse utilizada de forma idônea, somente as folias registradas poderiam concorrer à ela. Isso porque o olhar sobre as manifestações devocionais populares mudou, e hoje são consideradas dentro do escopo de cultura popular. Embora a ajuda não seja facilmente alcançável e hoje com o achatamento das verbas destinadas à promoção da cultura, mais inalcançável tenha se tornado, a sua existência por si só já atesta essa mudança. Além das 
questões burocráticas a dona da folia administra o dinheiro dos giros e, muitas vezes, tirar do próprio orçamento para compor o do grupo. Ela organiza as festas, pelo menos a de Coroação, início do giro, e não raramente a de descoroação também, que encerra o giro. Supervisiona a organização do roteiro, quando não participa ativamente. Cuida da bandeira, dos uniformes e dos instrumentos, mantendo tudo em sua casa sob sua tutela, assumindo assim também a função de Madrinha da Bandeira.

É necessário salientar que "ainda hoje, as mulheres carregam o estigma de sexo inferior" (CRUZ, 2013, p. 66). A maioria "ainda resiste em ocupar os pequenos espaços de poder na direção das organizações. Talvez seja pelo fato de entenderem, ou de lhes ter sido ensinado, que poder é coisa de homem" (CRUZ, 2013, p. 66). Dessa forma é relevante compreender o que é ser dona de uma folia para essas mulheres, que tipo de poder elas detém.

"O poder como 'exercício de um serviço' é muito presente na vida das mulheres" (CRUZ, 2013, p. 66). Pois elas são ensinadas a servir, obedecer e serem dóceis desde a mais tenra idade. As mulheres que lideram os grupos e assumem, conscientemente ou não, uma função de poder, costumam pensar que estando à frente de uma folia elas não estão exercendo o poder, mas sim assumindo um compromisso com os santos Reis de não deixar a folia parar, de manter, como dizem, o folclore vivo. Mas elas são encaradas de fato como figuras de liderança dentro dos grupos e muitas vezes, na comunidades, como Maú, ou enquanto lideranças religiosas, como Luíza. Por isso, todas as decisões devem passar por elas antes de serem efetivadas. Até mesmo a configuração do roteiro do próximo giro não deve ser definido sem passar por sua autorização.

Quando Luiz Cláudio, vice presidente da Folia da Luíza, traçou o roteiro contemplando as casas de Tebas no dia 6 de janeiro, dia de maior relevância para a folia, o fez com a anuência de Luíza. Lembrando que as casas visitadas não eram de devotos de Santos Reis e sequer conheciam a sequência ritual, o que já configura uma diferença do perfil das visitas tradicionais.

Em um primeiro momento, fiquei um pouco descontente de encontrar pessoas que de fato não eram devotos de Santos Reis recebendo a folia, não de surpresa, mas em roteiro traçado anteriormente. Quando o roteiro é planejado, geralmente é por pedidos de devotos que fazem questão da presença da folia em suas casas, seja para pagar uma promessa, seja pela bênção anual da bandeira. Em uma análise mais imediata da situação encontrada, considerei o acolhimento da folia por parte daquelas pessoas mais por uma questão talvez de conhecer o exótico ou de se sentir mais próximo das camadas populares do que por um sentimento de devoção. Poderia se pensar primeiro que Tebas não possui a tradição da Folia de Reis tão 
forte quanto em Leopoldina. Mas a hipótese não se aplica, pois Tebas é uma cidade vizinha e bem menor que Leopoldina. Se todas as pequenas cidades e lugarejos da região cultivam essa tradição, porque Tebas fugiria da regra? Acredito que a falta de conhecimento notada seja por uma questão de classe social.

As famílias abastadas no passado recebiam as folias assim como as menos favorecidas economicamente. Quem dedicava devoção aos Três Reis faziam jatares para oferecer à sua bandeira em troca de sua bênção independente da classe social. As famílias abastadas de hoje, consideram por um lado, a Folia de Reis algo do passado, distante, festa das camadas populares que insistem em cultivar uma tradição quase perdida ou esquecida. Por outro, se identifica aos poucos, o discurso que esboça um desejo de resgate de uma tradição que se julga em vias de extinção, algo que não se pode deixar perder pela ação do tempo e pelo efeito homogeneizador da modernidade e suas estratégias de globalização. $\mathrm{O}$ que essas pessoas bem intencionadas não sabem por não terem contato com a festa, é que a Folia de Reis não vai se extinguir, independentemente de sua boa vontade em ajudar, chamando em suas casas o distante e exótico da periferia. A Folia de Reis possui uma dinâmica de auto renovação eficiente, contando com estratégias de substituição, ressignificação, flexibilização e alterações miticamente plausíveis. E apresenta uma rede devocional forte, que sustenta grupos e assistência, ou seja, não faltarão foliões e nem plateia. As crianças são inseridas desde cedo na folia que é uma forma lúdica de demonstração de fé e aprendem a acreditar nos Santos e seus poderes taumaturgos, porque ouve suas mães e familiares atestando com convicção a veracidade de seus feitos. Como assevera Geffré (2013, p. 231), “uma tradição só é viva se ela for sempre inovação".

\section{Festivais: devoção e resistência}

Além de toda essa capacidade de renovação intrínseca da Folia de Reis enquanto manifestação devocional e cultural, existem iniciativas relevantes no sentido de valorizar as manifestações de cultura popular e particularmente voltadas para a Folia de Reis em Leopoldina e região.Em Recreio, município próximo a Leopoldina, ocorre entre os meses de dezembro e janeiro um dos eventos culturais mais populares da cidade, a Festa em Honra a Santos Reis e o Encontro de Folias de Reis. O evento acontece anualmente no Cruzeiro dos Santos Reis. Segundo um dos atuais organizadores, Matheus Ribeiro, responsável desde de 2012, o festival se inicia no dia 30 de dezembro e termina geralmente dia 6 de janeiro. Mas 
como nesta última edição haviam muitas folias inscritas, o evento se estendeu por mais um dia, encerrando no domingo dia 7de janeiro.

A Festa e o Encontro que acontecem há 27 anos, reúnem um grande número de grupos de toda a região, e até mesmo folias de outros estados, como do Rio de Janeiro, já prestigiaram o evento tradicional na cidade. No giro de 2017/2018, a Folia da Luíza e a Folia da Luíza fizeram suas apresentações no Encontro no mesmo dia, onde tive a oportunidade de acompanhá-las.

Além desse evento em Recreio, há outro que reúne Folia de Reis de Leopoldina e região, com o objetivo de promover mostras e não duelos entre os grupos. $\mathrm{Na}$ zona rural de Leopoldina, nas Palmeiras, é organizado anualmente o Festival de Folia de Reis das Palmeiras, no Centro de Aprendizagem Comunitária - CAC. O Festival está em sua $35^{\mathrm{a}}$ edição e, segundo Tinho e Lúcia, que sempre esteve inserida na organização do Festival desde o princípio, foi o primeiro evento com o objetivo de reunir os grupos da região:

Lúcia: Quando começamos o festival lá, era, foi, .... meu pai, que já faleceu, era o Valdete, que é um dos fulião lá que já faleceu também, e o ...

Tinho: Meu pai também e o seu também..

Lúcia: E o pai dele. Entendeu? Então foi na época que a gente sentou pra conversa pra podê...

Tinho: Aí reuniu pra fazê o festival.

$[\ldots]$

Lucia:Por que então a gente não reunir todas essas folias em um mesmo lugar? Lá tem o CAC. Por que a gente não vai fazer uma festa pra fulia e tudo? E aí na época até foi falado vamo fazê um encontro de fulia. Meu sogro até falô: "Não. Não pode tê nome de encontro, porque num pode sê Encontro de Fulia, porque Encontro de Fulia tem otro sentido". Tendeu? Aí por isso surgiu o Festival de Fulia. [...]Aí é pra sê uma festa e não um Encontro. Por isso que chama festival. E desse festival quantos já tem por aí depois do nosso! Quantos já tem por aí na região! [...] Tinho: mas o primeiro foi o nosso lá. ${ }^{13}$

A iniciativa partiu da Emater em conjunto com a então diretoria do CAC. Lúcia acrescenta que quem iniciou o projeto foi Alfredo, que era presidente do CAC, seu pai Odair e Valdete, que são foliões e ela na organização, além do Oswaldo e Maria Helena da Emater, que agora já estão aposentados.

Lúcia tem uma trajetória relevante dentro da Folia de Reis, pois desde seu nascimento, toda sua infância, juventude e vida adulta esteve inserida nesse contexto. Seu pai, irmãos, tios e primos são foliões. Ela não se tornou foliona, mas sempre esteve inserida nesse ambiente, participando da organização, adquirindo conhecimento sobre as sabedorias ehistórias entorno da folia e vivenciando o ritual. É ela a responsável pelo almoço da Entrega da Bandeira da

\footnotetext{
${ }^{13}$ Entrevista realizada com Lúcia, em sua residência, no dia 10 de outubro de 2017.
} 
Folia da Serra na Igreja do lugarejo, que agrega um grande número de devotos, visitantes e moradores. Ela se reúne com algumas mulheres e elas fazem toda a comida servida no dia 6 de janeiro, no ritual de encerramento do giro.

Só a sua participação nas funções tradicionalmente destinadas às mulheres já serviria para traçar uma discussão entorno da participação feminina na folia. Porém, a colaboração de Lúcia não se resume aos locais tradicionais demarcados pela presença feminina, nos contexto privados e nas funções de extensão de atividades domésticas. Ela amplia as fronteiras que demarcam o lugar da mulher no universo da folia. Ela não se limita ao ambiente privado e assume liderança em locais públicos, como no Festival de Folias das Palmeiras, onde participou desde sua idealização no setor da organização e atualmente desponta como mestra de cerimônia do evento. Atua anunciando a entrada dos grupos, dando detalhes sobre sua formação e citando o trecho selecionado para apresentação, e tem autonomia de decisão. Um exemplo dessa autonomia foi o fato de ela ter me chamado para presentear a Folia da Serra com a lembrança do Festival. Ela não tinha certeza que eu iria, mas quando me viu resolveu me chamar ao palco para fazer a homenagem. Na verdade, quem se sentiu homenageada fui eu, que tive o prestígio de entregar a lembrança à folia mais antiga e mais tradicional de Leopoldina, tive oportunidade de falar sobre minha experiência e sobre o valor daquela folia e agradecer o acolhimento e carinho deles comigo.

Tinho, orgulhoso da atuação da esposa, reconhece a mudança de cenário dos tempos antigos para o atual, mesmo não aceitando tal mudança no interior de sua folia, admite o sinal dos tempos no seu entorno:

Tinho: Porque antigamente, a mulhé era assim, uma coisa bem distante, né?! O homem que..., né?!

ABN: encabeçava...

Tinho: O homem que encabeçava tudo. [...] Hoje num existe mais isso, né![...] Cê vê! Hoje o Festival da Fulia lá, cê presenciô lá, a mulhé que tá na frente lá, né?! Anunciano as fulia. Ela que faiz! É ela quem anuncia as fulia lá! ${ }^{14}$

Não só os eventos anuais, mas também os que são organizados esporadicamente, buscam dar maior visibilidade às manifestações de cunho popular. Um deles que tive oportunidade de participar foi o V Encontro de Tradições Mineiras, em Leopoldina, em outubro de 2010.Reuniu grupos deCongado, Mineiro-Pau, Capoeira, Jongo e Folias de Reis,

\footnotetext{
${ }^{14}$ Entrevista realizada com Lúcia, em sua residência, no dia 10 de outubro de 2017.
} 
em dois dias de vivências culturais compartilhadas. Em março de 2013, houve o IV Fórum de Culturas Populares da Zona da Mata, com o objetivo de abrir mais um espaço de troca de experiências, divulgação dos saberes tradicionais, além de viabilizar o acesso à informação sobre recursos financeiros municipais e formas de organização.

Porém, o Fórum de Culturas Populares e o Encontro de Tradições Mineiras acabaram perdendo força quando o organizador responsável mudou de Leopoldina e as leis de incentivo à cultura foram sendo reduzidas e se tornando cada vez mais escassas. Contudo, o Festival de Folias de Reis das Palmeiras e o Encontro de Folias de Reis de Recreio ganham popularidade e visibilidade a cada ano, mesmo com parcos recursos. Segundo um dos organizadores do Encontro de Folias a prefeitura de Recreio ajudou apenas com a carne para o lanche dos foliões (pão com molho de carne moída e refrigerante) e com equipamentos de som. Já para o Festival das Palmeiras, Lúcia aponta que o auxílio da Prefeitura de Leopoldina se delineou no sentido de oferecer ônibus para o transporte dos foliões da cidade para o CAC e seu retorno. O que se pode perceber é que a atuação do poder público junto a esses eventos não se dá no sentido de motivar suas práticas, mas mesmo assim alguns resistem e seguem com a vontade a frente do dinheiro. Mesmo assim, a popularidade desses eventos mostra que o olhar sobre essas manifestações mudou, e o que era periférico e marginal, ganha relevância enquanto cultura popular e saberes tradicionais que devem ser valorizados.

Nesses eventos, tanto o das Palmeiras, que é zona rural, quanto o de Recreio, um pouco mais distante, recebem a participação dos grupos aqui estudados. Palmeiras recebeu a Folia da Serra, a Folia dos Colodinos e a Folia da Maú. Recreio recebeu a Folia da Luíza e a Folia da Maú. Como pode-se perceber, Maú é bem atuante no cenário folião leopoldinense e se insere, há muitos anos, em todos esses eventos, inclusive nos fóruns de debates e encontros de tradições mineiras. Também por essa inserção, o grupo consegue se estabelecer há tantos anos nesse contexto.

Em vários casos de folias com liderança femininas, se a mulher não assumisse a direção diante da situação de perda do dono anterior, como Maú assumiu, o grupo se diluiria. Sem uma figura de respeito, que religa todos os integrantes, possui voz de comando, empreende atitudes e ações que fazem a festa acontecer, o grupo não segue adiante. No ano em que Maú adoeceu, final de 2016, sua folia não saiu em giro, ou seja, mesmo tendo passado o cargo de dona para seu filho, sua figura é fundamental para a dinâmica do grupo.

No caso da Folia da Luíza, o grupo só nasceu por conta de sua fé. No final de 2017, dia 23 de dezembro, na véspera do início do giro da folia, Luíza veio a falecer, depois de passar pouco mais de uma semana no hospital. Porém, já havia deixado tudo preparado para a 
saída da folia. Segundo Andreia, sua filha mais velha, só faltava buscar os uniformes novos na costureira, que Luíza gostava de renovar todos os anos. Partedo dinheiro Luíza já havia separado para pagar o serviço, a outra parte a costureira deixou Andreia pagar quando tivesse condições. Ao contrário da Folia da Maú, que não saiu em giro sem a sua presença, a Folia da Luíza saiu em respeito à vontade da dona da folia, ao seu empenho, à sua dedicação em vida. Em homenagem à sua memória, a filha não permitiu que a folia não cumprisse com sua missão neste giro. Dessa forma, tudo foi feito como a matriarca havia planejado. Visitaram todas as casas contempladas pelo roteiro e viajaram para Recreio, no dia 6 de janeiro.

\section{Obstáculos e estratégias de permanência}

A partir desse cenário em que as mulheres se apresentam autônomas e atuantes em todos os setores da folia, tanto no topo quanto na base da manifestação, é possível perceber que a folia ressemantiza alguns aspectos próprios para buscar aderência no contexto social atual e fagocita certos traços da cultura hegemônica, se valendo deles como facilitadores, se remodelando e assim gerando resultados criativos. Usando exemplos bem simples, se antigamente, ao bater da folia em casa as mulheres corriam à cozinha para assar uma broa e passar um café, hoje, com a rota traçada anteriormente, a casa espera a folia com refrigerante e hot dog, e não há mal nenhum nisso, pois a essência da folia permanece a mesma. Segundo Woodward (2000, p.20) "a globalização envolve uma interação entre fatores econômicos e culturais, causando mudanças no padrão de consumo, as quais por sua vez produzem identidades novas e globalizadas." Se os efeitos da globalização, atrelados ao crescimento da industrialização dos gêneros alimentícios e sua midiatização, atingiram nossos consumo e hábitos alimentares, isso não corrompe a fé dos devotos, que sustentam a Folia de Reis.

$\mathrm{O}$ acesso irrestrito ao celular por grande parte da população e sua facilidade em registrar imagens, acaba divulgando a manifestação em redes sociais e diluindo aos poucos a imagem negativa que os foliões carregam há muito tempo ${ }^{15}$, de marginais, cachaceiros e vadios, aliada ao preconceito de cunho religioso. Além disso, o uso de aplicativos como o whats app, facilitam e agilizam a comunicação e confirmação de visitas para montar o roteiro.

Portanto, em relação à Folia de Reis em Leopoldina é possível afirmar que a festa possui aderência ao contexto social do lugar. E não por conta do dinheiro garantido nos giros,

\footnotetext{
${ }^{15}$ Bastos (1973, p. 32), na década de 1970, sinalizava a institucionalização do preconceito sobre a Folia de Reis, devido à ação policial que tentava minar suas atividades nas áreas urbanas através de uma "sistemática prevenção das forças policiais que sempre consideraram esse tipo de folguedo como arregimentação de marginais".
} 
muito menos por conta de alguma verba municipal que a cada dia se torna mais inatingível, mas por dois elementos que se associam de maneira bastante harmônica e prazerosa: fé e lazer. Luíza mesmo asseverava que o motivo de não encerrar o giro de seu grupo no dia 6 de janeiro, como manda a tradição, é pelo número de casas que pede a visita da folia e que aumenta a cada ano:

Luiza: primeiro, não dá tempo de visitar todas as casa até o dia 6. Aí sempre fica as pessoas, que já tão acostumada, as pessoa devota recrama cum a gente. Então como agora,.. todo mundo agora, praticamente todas as fulia, vai até o dia 20 por esse motivo. Num é por que a gente qué... tem gente que fala assim: é meio de vida. Não. Não é meio de vida. A gente qué agradá a todos, a gente qué chama mais as pessoas pra fé, pra, pra, acreditá, confiá, procurá a verdade. Porque a verdade, é qui o santo é milagroso. Então a gente qué é isso aí. Então o qué qui a gente faiz? Pra num pará dia 20, dia 6, a gente vai até o dia de São Sebastião, qui aí dá tempo de visita todo mundo. [...] Já aumentô casa esse ano! ${ }^{16}$

\subsection{Jovens e a de Folia de Reis}

Por mais que os foliões garantam que a folia enfraqueceu em relação ao passado, o que se vê na dinâmica do giros é uma estrutura forte com ampla participação popular. Se por um lado Bento, genro da Luíza, afirma em entrevista que a folia estava acabando e Luíza assevera que quando os velhos morrem os jovens não têm incentivo para continuar, por outro lado o que se percebe no campo é uma manifestação religiosa vigorosa e uma tradição que avança sem perder suas raízes. A própria Luíza revela que quando ela criou sua folia seu filho já tinha mais de 20 anos de giro. Pois ele saía na folia de seu primo desde cedo. Os jovens configuram a maioria na Folia da Luíza. Não parece que a nova geração precise de incentivo para manter a tradição, pois eles sentem prazer nisso.

Por outro lado Lúcia assevera que a Folia da Serra tem muitos jovens: "Nós temos muitos jovens. Muitos jovens na fulia. Meu filho mais novo, tá com 24 anos, hoje já é um mestre na fulia. Tendeu? Então assim, é um envolvimento muito grande, temos muitos jovens." 17

No Festival de Folia de Reis das Palmeiras a Folia mirim do Arrasta Couro se apresentou. Todos os foliões são crianças ou adolescentes que não pareciam encarar a atividade como brincadeira, mas sim como uma prática devocional, que não deixa de ser lúdica. E Matilda acrescenta que, apesar dos jovens não se interessarem por folia, na Folia dos Colodinos eles já começam a ser integrados no grupo a partir dos antigos foliões:

\footnotetext{
${ }^{16}$ Entrevista realizada com Luíza, em sua residência, no dia 17 de junho de 2017.

${ }^{17}$ Entrevista realizada com Lúcia, em sua residência, no dia 10 de outubro de 2017.
} 
Matilda: E hoje essa juventude que evem aí, ocê eu nem sei cumé qui ocê mexe cum isso...

ABN: Ihh eu adoro!

Matilda: Ninguém mais gosta, tá?! Num é? Cê num vê mais ninguém novo falá que gosta.

ABN: São poucos que dão continuidade à folia da família, né?! Igual lá da Serra eles dão, né?! Tem que ser uma coisa mais de família...

Matilda: Igual a dos Colodino também tá dando. Us minino do seu Darilo. Pois intão. O seu Darilo já vai, tá ficano véi já, mas já evem. Tem dois neto dele já que já tá na fulia. ${ }^{18}$

\subsection{Trânsito religioso}

Os fatores que favorecem uma queda no número de folias em relação ao passado são inúmeras. E embora a manifestação se adapte a novas situações e se ressignifique para seguir em frente, é certo que fatores dificultadores, mesmo contornados, levem a uma adesão menor do que antes ela possuía, tanto adesão de quem participa como foliões como também assistência. Um fator que pode ser citado é o trânsito religioso observado atualmente. Leopoldina desenvolveu-se como um município essencialmente católico. Ainda hoje, segundo o censo realizado pelo IBGE em 2010, a religião é professada por aproximadamente $72 \%$ da população. Por outro lado, essa hegemonia é paulatinamente contrastada pelo crescente número de evangélicos e a expressiva queda dos católicos. No ano $2000,80 \%$ da população se identificava como adeptos do Catolicismo. Ainda que nesse município o número de evangélicos em 2010, aproximadamente $16 \%$ da população residente, encontre-se abaixo da média nacional ${ }^{19}$, que se aproxima dos $22 \%$, é possível observar seu crescimento nesse período $^{20}$. É conhecida a aversão que os evangélicos professam em relação à adoração de santos e consequentemente às festas em sua homenagem. Em relação à Folia de Reis, ainda tem um agravante, que seria a participação não só dos católicos mas também dos umbandistas, que é um grupo frequentemente hostilizado pelos evangélicos, compreendidos não raramente como adoradores do demônio. Em entrevista, o presidente do Conpas (Conselho de Pastores de Juiz de Fora), destaca a relação que ele acredita existir entre as religiões de matriz africana e o demônio:

\footnotetext{
${ }^{18}$ Entrevista com Matilde em sua residência, dia 13 de abril de 2017.

${ }^{19}$ Minas Gerais se apresenta como um peso morto na região Sudeste em relação às estatísticas de crescimento protestante (FRESTON,1994, p.31).

${ }^{20}$ Em Leopoldina, o Censo de 2010 apresenta grande avanço dos pentecostais e neopentecostais. Embora a Igreja Universal do Reino de Deus (IURD) tenha registrado uma pequena queda no número de fiéis, a Assembleia de Deus registra um expressivo aumento. De acordo com dados do IBGE em Leopoldina, a IURD em 2000 apresentava 389 fiéis e, em 2010, 353. Já a Assembleia de Deus, que apresentava 1764 membros em 2000, no último censo conta com a presença de 2108 fiéis na cidade.
} 
eles estão completamente fora dos princípios da palavra de Deus. Prova disso, é eles sabem que eles recebem guia, baixam neles guia, que são demônios. Eles têm pactos demoníacos. [...] Aí cê fala assim: mas por que as pessoas ficam lá pastor? Porque elas vão prá lá pra receber alguma graça. Elas vão prá lá receber alguma cura. E são curadas! Aí cê fala assim: mas por que elas são curadas, pastor? Não é Jesus que cura? Jesus num tá lá! Tá? Eu digo prá você: Não. Tá não. Mas por que elas são curadas? Porque o diabo é enganador. Ele tem o seu poder limitado.[...]Então a pessoa é curada não por Deus, mas por demônios, e os pais-de-santo sabem disso! Então o que acontece num terreiro de umbanda, quimbanda, candomblé? Eles fazem também alguns sinais, até pra provar que aquela religião é certa. Mas não é. Claramente quem age ali é o próprio inimigo. Então o que eles fazem? Os pais-desanto recebem os guias, que é o espírito incorporado neles, como nós também recebemos, porém o Espírito Santo ${ }^{21}$.

Essa visão recorrente entre os evangélicos, é associada à Folia de Reis por serem muitos umbandistas adeptos da manifestação e devotos de Santos Reis. Por falta de conhecimento da simbologia de cada personagem, de seus papéis dentro da festa, aliada à aparência assustadora do palhaço e a adesão de umbandistas, já ouvi diversas vezes evangélicos dizerem que Folia de Reis também é coisa do diabo. Além disso, em Leopoldina, alguns evangélicos costumam mostrar sua intolerância em relação aos católicos e umbandistas concomitantemente dizendo a seguinte frase: todo bom católico é também um bom macumbeiro! Isso porque, muitas vezes o umbandista declara sua dupla pertença. Como Luíza revela em entrevista:

A verdade é que nós somo católico espírita. Por que o católico espírita? Nós vamos à Igreja, faz batismo, a gente reza, a gente vai à missa, tudo normal! Se tem que mandá celebrá uma missa pum ente, a gente manda normal, a gente vai, tendeu? A gente assiste casamento, é madrinha de batismo. Tudo normal! Tendeu? E a gente tem esse lado espiritual! Aquele lado qui a gente tá dentro do centro, que tem que fazê o bem sem vê a quem, tendeu? Se alguém precisô a gente tem que tá ali pronta prá ajuda, intendeu? Deus deu o dom num é prá comprá, num é prá sê vendido, é pra gente fazê, tudo ali. ${ }^{22}$

Dessa forma, não é por ser uma manifestação no senso comum reconhecida como católica, que o público evangélico vai deixar de hostilizar. Pois a festa enquanto manifestação religiosa é professada tanto por católicos, quanto por umbandistas, quanto por católicos espíritas, como a dupla pertença é conhecida. E quando uma pessoa entra para igreja ou para a crença, como se referem às pessoas que fazem o trânsito religioso para confissões evangélicas, ela consequentemente sai da folia e não recebe mais em casa. Então, esse novo campo religioso que cresce é um fator que contribuiu para a perda de adeptos da folia. Mas

\footnotetext{
${ }^{21}$ Entrevista com o então Presidente do Conpas em 2013, na Igreja Resgatando Vidas, em Juiz de Fora, MG.

${ }^{22}$ Entrevista realizada com Luíza, em sua residência, no dia 17 de junho de 2017.
} 
como o trânsito é sempre dinâmico, assim como as pessoas entram para as igrejas, também deixam e voltam para a folia.

\subsection{Empregos urbanos}

Mais um fator que interfere hoje na sequência dos giros são os trabalhos urbanos.

Em conversas informais e em entrevistas foliões, folionas e assistência atestam que no passado os foliões saíam de casa no dia 24 de dezembro depois da meia noite e só voltavam no dia 6 de janeiro para a Entrega da Bandeira. Dormiam onde sua bandeira recebesse pouso, ou seja, se já estivessem cansados para prosseguir com o giro e visitar mais casas naquela noite ou madrugada, pediam pouso na última casa e dormiam em qualquer lugar que oferecessem, no paiol, no chão, ou onde os donos da casa disponibilizassem. Como Matilda explica em entrevista:

Matilda: Uai, antigamente a nossa fulia saía à meia noite do dia, no dia de natal, né... ABN: dia $24 \ldots$

Matilda: É. Meia noite. E ela só parava dia 6. Na nossa época, né. Quando nóis era criança. Eu tinha o quê? 9, 10 ano. E a gente acompanhava, acompanhava. De casa em casa. E eles num parava pra ir pra casa des não. Aquilo ia, ia até dia 6.

$[\ldots]$

Matilda: Aí era na casa do meu tio, João Boninho. Lá ele recibia as fulia. Eles ou almoçava ou jantava. E depois do almoço eles durmia. Lá pra fora. Cada um istendia suas coisa lá e durmia. Até num pano véi mesmo eles durmia.

$[\ldots]$

ABN: E você sabe como era assim a questão de trabalho deles? Eles paravam de trabalhar nessa época?

Matilda: Parava, parava... isso até hoje ainda tem muitas fulia que ainda pára, né?![...] Os da roça é, os antigo é. Os antigo pára. [...] Mas hoje eles não vira dia e noite, né?! Antigamente eles virava dia e noite. Hoje não. Hoje eles toma o banho deles e vem, né?! Vai numa casa, vai ni 2 , vai ni 3 só. ${ }^{23}$

A partir desse relato é possível perceber a diferença entre as folias antigamente e as folias atuais. As casas visitadas eram de pessoas conhecidas, de familiares dos foliões, então a intimidade lhes dava a liberdade de pedir o pouso à bandeira e aos foliões. Atualmente, com os foliões dependendo de seus empregos urbanos, as visitas das folias acabam sendo mais numerosas nos fins de semana. Lúcia, em entrevista, explica que hoje o envolvimento dos foliões com as folias não é como no passado muito por conta de seus empregos e não por falta de fé. Assim, ela justifica:

\footnotetext{
${ }^{23}$ Entrevista com Matilde em sua residência, dia 13 de abril de 2017.
} 
Mas talvez seje por causa de trabalho, né, porque as firmas não liberam... durante a semana. Então isso acabô atrapalhano um pouco. Porque naquela época era só o povo que trabalhava na roça. E aí era diferente por causa disso. Que era só quem trabalhava na roça então as pessoas já contornava a sua vida pra podê saí na fulia sem... tinha menos, né, problema. Hoje depende muito de férias, né! Depende de uma série de coisas pra, pra continuá. ${ }^{24}$

Como antigamente grande parte dos foliões era trabalhador rural, a flexibilização do trabalho nos dias de giro da folia era negociado com o patrão. Os foliões faziam um mutirão para adiantar, nas semanas anteriores, os serviços uns dos outros. Às vezes, o próprio patrão também era devoto de Santos Reis, e se não fosse, respeitava e compreendia a dinâmica dos giros como algo natural e relevante.

Por conta dos empregos urbanos, as folias acabam estendendo os giros para além do dia 6 de janeiro para conseguir atender todos os devotos.

\subsection{Misoginia}

Antigamente, a maioria das casas recebia as folias que passavam. Hoje, o roteiro é traçado previamente para não se perder tempo com pessoas que não querem, podendo assim dar preferência aos devotos que pedem a visita e podem traçar um caminho que vá atender o maior número de casas próximas no mesmo dia. Com a visita já marcada, os donos da casa podem preparar o lanche previamente também.

Por mais que traçar roteiro ainda seja uma função masculina em muitos grupos, inclusive aqueles que contam com lideranças femininas, elas são consultadas antes de iniciar tal roteiro e ao término dele. Pois muitas vezes os devotos conversam diretamente com as lideranças do grupo para pedirem a visita da bandeira no próximo giro. Para não deixar nenhuma casa sem a bênção, eles organizam o roteiro sempre com a anuência do dono ou dona da folia. Se antigamente o roteiro das casas a receberem a visita das folias era definido na hora do giro, hoje é pré-determinado, calculando assim o tempo de caminhada por noite e evitando os contratempos já citados.

Mesmo com as mulheres assumindo funções de comando nas folias, a misoginia ainda é um obstáculo contemporâneo. Assim como o problema do preconceito racial, a superação da misoginia na folia não é uma realidade, mas sim uma possibilidade. E o que garante essa

\footnotetext{
${ }^{24}$ Entrevista realizada com Lúcia, em sua residência, no dia 10 de outubro de 2017.
} 
possibilidade é seu respaldo mítico, ou seja, a narrativa das Três Marias ${ }^{25}$.O que pode ser observado é que em prol de um bom funcionamento dos giros, as narrativas míticas celebram uma flexibilização das regras que engessavam uma estrutura, que por sua vez, só se sustenta na maleabilidade da concessão. Mas o que deve ser ressaltado é a ideia de acolhimento das mulheres nesse contexto falocrático. Talvez não um acolhimento no sentido de se tornar parte de um contexto de modo solidário e ser tratada como igual. Mas sim no sentido de se ressaltar a natureza externa desse elemento. Se a mulher foi acolhida na folia, quer dizer que aquele espaço não lhe pertence originalmente, que não é seu, mas ela pode permanecer. Justamente por ser relevante em vários aspectos. Igualmente como acontecia e ainda acontece com os negros em folias de famílias brancas, a ideia de acolhimento do elemento não pertencente é o mesmo.

\subsection{Preconceito racial}

O preconceito racial, um elemento arraigado na cultura de Leopoldina, segundo Franklin (2014) a cidade negra de mando branco,também foi um obstáculo importante, que no passado, impedia o desenvolvimento dos giros. Muitas vezes se perdia a oportunidade de contar com um hábil instrumentista, que fazia falta no grupo, por conta de sua cor. A narrativa que versa sobre a exclusão de Baltazar da jornada pelos outros dois Reis Magos ${ }^{26}$, faz uma analogia à realidade vivida. De acordo com o Seu Didi, folião dos Colodinos, o motivo da exclusão de Baltazar era puramente racista, pois na visão dos reis brancos, não ficava bem para eles serem vistos andando por aí na companhia de um negro. Isso reflete o pensamento em vigor na época em que a narrativa foi legitimada, que não valia apenas para os Reis mas também para seus representantes, os foliões. Atualmente a inclusão de participantes negros em folias de famílias brancas é miticamente justificada.

\footnotetext{
${ }^{25}$ Tal narrativa justifica a presença feminina no cortejo através da reinvenção do mito fundante. Um folião da Folia dos Colodinos contou que numa encruzilhada os três Reis encontraram com as três Marias, e sabendo do destino dos Reis elas pediram para acompanhá-los, pois também gostariam de conhecer o Salvador, e eles aceitaram a companhia feminina. Isso respalda miticamente a presença feminina no cortejo e na esfera ritual da folia.

${ }^{26}$ A narrativa também se pauta na reinvenção do mito fundante. De acordo com a narrativa contada por seu Didi, durante a noite, quando os Reis pararam para descansar, os dois Reis brancos combinaram de sair de madrugada, antes de Baltazar despertar, pois não seria interessante para eles serem vistos na companhia de um negro. Quando Baltazar acordou e se viu sozinho, a estrela apareceu para ele e o levou até a manjedoura, sendo ele o primeiro a chegar para adorar o menino Jesus. Logo depois, os outros dois Reis, que anteciparam a sua viagem, atônitos observaram o que havia acontecido e aprenderam que não deveriam ter excluído Baltazar por conta de sua cor.
} 
Ainda hoje, não é difícil encontrar em Leopoldina folias de famílias predominantemente negras e predominantemente brancas. Até porque, após a abolição e a partir do desenvolvimento das cidades, os negros foram impelidos a ocupar a periferia de forma propositalmente excludente. De modo que uma barreira tanto territorial quanto psicológica fosse imposta de forma aparentemente intransponível, dividindo negros e brancos na cidade. Assim, as redes familiar e de vizinhança, que surgem nas periferias leopoldinenses, imprescindíveis na formação dos grupos, são compostas majoritariamente por negros. Dessa forma, a Folia da Serra, rural, é de maioria branca, a Folia da Maú e da Luíza, predominante negra e na Folia dos Colodinos, aparecem negros e brancos tocando juntos. Mesmo assim, o número de negros é muito inferior ao de brancos, muitos deles são frutos de uniões “interraciais" mais recentes na família. O baixo número de negros no grupo dos Colodinos deve ser encarado com estranhamento, já que a família de Juca Colodino quando veio da zona rural para a cidade se fixou na periferia, no bairro do Alto do Cemitério, onde o contingente de pessoas negras observado não é minoritário. Portanto, o avanço que pode ser apontado no sentido de superação do obstáculo do racismo na dinâmica da folia hoje é que não existe nada que miticamente, e portanto, oficialmente, impeça que negros e brancos participem do mesmo grupo. Pelo contrário, a narrativa mítica condena a exclusão racial, como mais uma estratégia de controle e permanência da folia no contexto social de Leopoldina e região.

\subsection{Preconceito de classe social}

O preconceito de classe social, no contexto da folia, pode ser atenuado com informação. Tais informações eram fornecidas à população a partir de fóruns e encontros, que discutiam a temática cultural com ênfase nas manifestações populares regionais. E como consequência, colocavam tais manifestações em evidência, promovendo um enfoque positivo, como cultura viva e não como crendice em vias de extinção.

Além desses eventos, extintos por falta de verbas, ainda temos os Festivais que promovem a exposição de cada grupo, mostrando a beleza e a dimensão cultural que agrega. Dessa forma, as casas na vizinhança deixam de ser os únicos lugares a receberem a visita das bandeiras das folias. Nas casas não há preocupação com o tempo, o mestre é quem dita a duração da visita de acordo com o pedido de cada família. Já nos eventos cada apresentação deve obedecer ao tempo estipulado pelo organizador.

O quadro a seguir foi construído para facilitar a compreensão de como a folia se readapta e se ressignifica a fim de contornar esses percalços, já que não foi possível evitá-los. 


\begin{tabular}{|l|l|}
\hline $\begin{array}{l}\text { OBSTÁCULOS (do passado e do } \\
\text { presente) }\end{array}$ & $\begin{array}{l}\text { ESTRATÉGIAS DE CONTROLE E } \\
\text { PERMANÊNCIA(ressignificações/readaptações) }\end{array}$ \\
\hline $\begin{array}{l}\text { Os velhos morrem e a juventude } \\
\text { não se interessa }\end{array}$ & Inserção de jovens e crianças na folia desde cedo \\
\hline $\begin{array}{l}\text { Opção religiosa- trânsito } \\
\text { religioso: }\end{array}$ & $\begin{array}{l}\text { - Dor parte do folião } \\
\text { possível. } \\
\text { - Roteiro traçado previamente }\end{array}$ \\
\hline - Por parte da assistência & $\begin{array}{l}\text { - Roteiro traçado previamente } \\
\text { - Extensão do giro até dia 20 de janeiro retorno é sempre }\end{array}$ \\
\hline $\begin{array}{l}\text { Eulheres não podem seguir em } \\
\text { giros com os homens }\end{array}$ & $\begin{array}{l}\text { Mito fundante reinventado: os Reis Magos } \\
\text { encontram as Três Marias no caminho e aceitam } \\
\text { sua companhia na jornada. As mulheres não } \\
\text { devem ser excluídas. }\end{array}$ \\
\hline $\begin{array}{l}\text { Ideia de folia como manifestação } \\
\text { do passado, crendice popular. } \\
\text { de famílias brancas }\end{array}$ & $\begin{array}{l}\text { Ideia da folia como manifestação cultural e que } \\
\text { deve ser resgatada. } \\
\text { sero não são aceitos em folias } \\
\text { encontro do Menino Jesus. Nenhum folião deve }\end{array}$ \\
\hline
\end{tabular}

Tabela 1: Relação dos obstáculo enfrentados pela folia para permanecer no contexto contemporâneo e suas estratégias de controle e permanência.

\section{Conclusão}

Nesse estudo importou ressaltar como a mulher, apesar de ainda marginalizada, conseguiu ascender à liderança de grupos majoritariamente masculinos. E mostrar como esse deslocamento, ainda que possibilitados miticamente, não supera o problema da misoginia dentro desse contexto devocional, que na verdade é um reflexo de um contexto social maior. Porém, a misoginia não foi o único problema ou obstáculo a ser superado ou, pelo menos, contornado, pela folia. Outros deslocamentos, que se entrelaçam foram necessários para a sua permanência no contexto social fosse possível. 
A trajetória da folia até a contemporaneidade foi marcada por vários percalços, dentre eles intolerância religiosa,trabalhos urbanos,misoginia, preconceito racial, preconceito de classe social. Obstáculos relacionados à discriminação devem ser superados na sociedade como um todo, e também na folia, onde é apresentado um jeito peculiar de lidar com esses problemas, mas não suas soluções. Pode-se compreender esse jeito enquanto estratégia de controle e permanência. São estratégias utilitárias, que resolvem a consequência do problema, mas não ataca e aniquila a origem do mesmo, justamente por estar atrelada a estruturas sociais mais profundas e de difícil desinstitucionalização. O modo como os preconceitos foram instaurados nas mentes e corações das pessoas foi tão eficaz, que mesmo se mostrando como elementos que impedem ou prejudicam nitidamente a dinâmica dos giros, não são facilmente desconstruídos. Se ainda é cedo para vislumbrar o fim da discriminação (seja ela qual for) na sociedade, no contexto folião foram criadas estratégias míticas de aceitação para minimizar os prejuízos que determinados preconceitos impunham aos giros. Isso não quer dizer que esses obstáculos foram superados, mas talvez contornados, tendo assim abrandados seus efeitos.

Portanto, se alguns elementos na atualidade se tornam obstáculos para o percurso natural da folia e são na maioria das vezes superados pela flexibilidade e capacidade de renovação da manifestação, outros fatores próprios da atualidade também abrem oportunidades de ampliação da assistência.

\section{Referências}

BASTOS, Wilson de Lima. Folclore no setor religião em Juiz de Fora. Juiz de Fora, Edições Paraibuna, 1973.

CRUZ, Maria Isabel da. A mulher na igreja e na política. São Paulo: Outras Expressões, 2013.

FRANKLIM, Margareth Cordeiro. Cutubas: clube de negros, território de bambas: memória e patrimônio afrodescendente de Leopoldina- MG. Utopika editorial. 2014.

FRESTON, Paul. O Mapeamento dos Protestantes Brasileiros. In: Protestantismo e Política no Brasil. Tese (Doutorado Unicamp), Campinas, 1994. p. 27-41.

GEFFRÉ, Claude. De Babel a Pentecostes: ensaios de teologia inter-religiosa. São Paulo, Paulus, 2013.

WOODWARD, Kathryn. Identidade e diferença uma: uma introdução teórica e conceitual. In: SILVA, Tomaz Tadeu (org.) Identidade e diferença: a perspectiva dos estudos Culturais. Petrópolis, RJ: Vozes, 2005. 


\section{"ORAÇÕES PARA BOBBY": A COSMOVISÃO CRISTÃ-PROTESTANTE ENTRE O DIÁLOGO E A TOLERÂNCIA NA QUESTÃ̃O DA HOMOSSEXUALIDADE \\ Prayers For Bobby ": The Christian-Protestant Cosmovision Between Dialogue And Tolerance In Homosexuality Discussion}

Giovanna Sarto Rubia Campos $^{27}$

Resumo: Este trabalho tem como objetivo um estudo acerca da construção histórico-social dos corpos no âmbito de um discurso moral de matriz cristã-protestante. Partindo de uma análise do filme "Orações para Bobby" nosso intuito é problematizar a perspectiva de sexualidade, de construção da heterossexualidade e dos papéis sociais, com recorte na questão da homossexualidade masculina, que subjaz a uma cosmovisão religiosa cristã protestante que, por sua vez, se entende como verdade absoluta. A importância dessa reflexão se justifica na medida em que tal moralidade se constitui como fundamento para a exploração, opressão e violência contra determinados grupos de indivíduos, neste caso os homossexuais masculinos. Examinando a obra cinematográfica, baseada em uma história real, buscaremos identificar e compreender o que fundamenta o discurso e a prática de uma família protestante tradicional da Igreja Presbiteriana dos Estados Unidos nos anos 1980, que considera mais cara sua cosmovisão religiosa cristã, do que a relação entre os próprios entes familiares, revelando assim, os limites da alteridade, da tolerância e do diálogo.

Palavras-Chave: Religião, Gênero, Violência.

Abstract: This article aims at a study about the social-historical construction of the bodies within a moral discourse of Christian-Protestant matrix. Starting from an analysis of the film "prayers for Bobby" our aim is to problematize the perspective of sexuality, construction of heterosexuality and social roles, with a cut in the question of male homosexuality, which underlies a Protestant Christian religious worldview, is understood as absolute truth. The importance of this reflection is justified insofar as such morality constitutes the basis for exploitation, oppression and violence against certain groups of individuals, in this case male homosexuals. Examiningthe cinematographic work, which is based on a true story, we will seek to identify and understand what underlies the discourse and practice of a traditional Protestant familyof the Presbyterian Church of the United States in the 1980s, which considers its Christian religious worldview more expensive than relationship between the family members themselves, thus revealing the limits of alterity, tolerance and dialogue.

Key Words: Religion, Sexuality, Violence.

\section{Introdução}

Orações para Bobby (2009) é um filme estadunidense dirigido por Russell Mulcahy e baseado no livro Prayers for Bobby: A Mother'scomingtotermswiththe suicide ofher gay son,

\footnotetext{
${ }^{27}$ Bacharéis em Ciências Humanas pela Universidade Federal de Juiz de Fora (UFJF). E-mails: giihsarto@hotmail.com; rubiacamposgc@gmail.com
} 
de Leroy F. Aarons (1995) ${ }^{28}$. O filme reconstrói parte da história real da família Griffth, uma família presbiteriana conservadora americana, que passa a ter que lidar com a questão da homossexualidade, quando um de seus filhos, Bobby, reconhece-se e assume-se gay. Mary Griffth, a matriarca e cristã devota que segue à risca a doutrina da confissão religiosa a qual pertence, passa a submeter o filho a rituais domésticos diários (oração, leitura bíblica e bilhetes com mensagens religiosas) e terapias psicológicas na intenção de "curá-lo" daquilo que ela entende ser um desvio. ${ }^{29} \mathrm{~A}$ pressão da família e o impasse dualista imposto pelo contexto religioso conservador no qual o rapaz está inserido- Bobby não podia ser cristão e gay ao mesmo tempo - culmina no suicídio do jovem. A partir de então, Mary entra em uma jornada de reinterpretação, vira o que chamamos aqui de "chave hermenêutica" e, após longos conflitos morais e éticos, torna-se, ao longo desse processo de ressignificação da doutrina e da pertença religiosa, umaimportante ativista da Associação Nacional de Pais e Amigos de Lésbicas e Gays dos Estados Unidos (P-FLAG).

A moralidade cristã conservadora de que fala Orações para Bobby constitui-se um importante componente na justificaçãoda exploração, opressão e violência contra grupos homossexuais. Mas o que exatamente fundamenta a perspectiva familiar que considera mais cara sua cosmovisão religiosa cristã do que a relação de reconhecimento e afeto entre os entes familiares? Refletindo a partir do filme é possível notar como um tipo especifico de cosmovisão cristã protestantereformada e conservadora é tão enraizada a ponto de não perceber o outro nas suas particularidades, o que, conforme nos releva o filme e a história da família Griffth, gera uma prática que podemos classificar como violência simbólica ${ }^{30} \mathrm{de}$ matriz religiosa, uma vez que impõe padrões normativos de gênero e sexualidade ${ }^{31}$ e tenta promover a manutenção da ordem, ainda que esta ordem não contemple a dinâmica familiar real, a partir de uma certa interpretação religiosa do que é certo ou errado. Essa prática é

\footnotetext{
${ }^{28}$ Disponível em:

https://en.wikipedia.org/wiki/prayers for bobby: a mother\%27s coming to terms with the suicide of he $r$ gay son> Acesso em: 23 de setembro de 2018.

${ }^{29}$ A ideia de "cura gay" foi bastante recorrente no século XIX, onde a apropriação do discurso religioso católico sobre a condenação da homossexualidade passa ao discurso médico-científico, legitimando a violência contra grupos LGBTs e a moral preconcebida da matriz cristã (SANTOS, 2013).

${ }^{30} \mathrm{O}$ conceito de violência simbólica desenvolvido por P. Bourdieu (2014) diz respeito a um certo tipo de violência que se estrutura enquanto mecanismo de dominação utilizado por diversas instituições sobre as quais se apoia o exercício da autoridade. Por meio desta, os indivíduos passam a ver determinadas representações sociais ou ideias dominantes como naturais, absolutas e inquestionáveis. Todos aqueles que não se enquadram nessas representações, passam a ser potencialmente alvos de atividade coercitiva, ainda que sutil.

${ }^{31}$ Usamos aqui os termos "gênero" e "sexualidade" de acordo com a compreensão foucaultiana, que define o primeiro como a organização social da relação entre os sexos e o segundo que tem seu lugar exatamente entre o corpo e a sociedade. Enquanto gênero possui caráter performático nas relações sociais diretas, à sexualidade é imposto um modelo disciplinatório, condizente com a moral social hegemônica.
} 
indissociável à construção cristã dos papéis de gênero e sexualidade, e torna-se ainda mais complexa quando inserida em um contexto declaradamente afeito à ortodoxia reformada. $\mathrm{O}$ questionamento dessa construção exige necessariamente uma ruptura radical, o que implica na saída do enclave conservador e na percepção da dúvida de uma certa hermenêutica da escritura sagrada cristã e da cosmovisão que a distingue, a fim de que seja possível uma abertura ao progressismo e ao acolhimento, movimento que acontece nas cenas finais do filme, em que a mãe chora ao compreender que não havia nada de errado com seu filho e abre espaço, então, para o diálogo e o reconhecimento da alteridade.

\section{Metodologia}

Para elaboração deste artigo partiremos da análise interpretativa de sete cenas específicas do filme Orações para Bobby ${ }^{32}$.Mais do que uma simples descrição categórica da narrativa que aborda a vida e suicídio de um jovem cristão-protestante gay, neste trabalho nos propomos a observar a construção dos papéis de gênero e seu acordo com uma moralidade cristã-ocidental (Nunes, 2000; Fontes, 2006; Louro, 2000; Santos, 2013; Castro, 2014), bem como o caráter performático das identidades de gênero e o conflito com um certo tipo especifico de cosmovisão cristã-protestante, além de um breve enunciado a respeito do conceito de violência simbólica (BOURDIEU, 2014).

Nosso objetivo não é meramente instrumentalizar o filme, mas, ao contrário, entender que a expressão cinematográfica aponta a um outro sentido do cotidiano, escancara questões que no dia a dia não percebemos (PIEPER, 2015). No caso de Orações para Bobby, o filme coloca-nos a pensar e problematizar como a violência de gênero se justifica dentro de uma determinada cosmovisão.

Seguiremos uma ordem não cronológica dos acontecimentos do filme, numerando arbitrariamente as cenas de acordo com a convenção teórica e prática do artigo. Sendo assim, chamaremos de cena 1 aquela mencionada primeiro no artigo, cena 2 a que se segue no decorrer da análise, cena 3 e assim por diante.

\footnotetext{
${ }^{32}$ Cena 1 - acontece entre 00:02:43 a 00:04:18 do filme;

Cena 2 - acontece entre 00:14:45 a 00:18:10do filme;

Cena 3 - acontece entre 00:31:33 a00:32:26do filme;

Cena 4 - acontece entre00:28:35 a 00:29:16do filme;

Cena 5 - acontece entre 00:53:06 a 00:54:36 do filme;

Cena 6-acontece entre 01:06:12 a 1:08:15 do filme;

Cena 7 - acontece entre 01:13:23 a 1:15:28 do filme.
} 
O primeiro momento do texto se encarrega de analisar as cenas 1 e 2 a partir do pensamento de Cornelius Van Til, teólogo holandês calvinista, radicado nos Estados Unidos e um dos fundadores do Seminário Teológico de Westminster. A ideia de que existem dois sistemas de vida antagônicos e incomunicáveis, e de que são esses sistemas que determinam a visão de mundo dos indivíduos (SOUZA, 2017) são fundamentais para a análise aqui apreendida.

No segundo momento, enunciamos brevemente a configuração dos papéis de gênero e da heteronormatividade como categoria excludente que é respaldada no discurso cristãoprotestante conservador na forma de violência simbólica, exemplificado sobretudo nas cenas 3 e 4, a partir da teoria foucaultiana de construção e dominação dos corpos.

$\mathrm{Na}$ última parte, tratamos da epifania de Mary e do processo que culmina na abertura ao diálogo e ao reconhecimento da alteridade. As cenas 5, 6 e 7 mostram esse movimento gradativo e de extrema complexidade subjetiva tanto da mulher quanto da família,o que culmina em uma nova forma de interpretação e comportamento religioso e social, que terá efeitos práticos consideravelmente relevantes.

\section{“Todos Os Veados Deviam Ser Enfileirados E Mortos": Uma Interpretação Literal E Conservadora Da Escritura}

A cena 1 do filme, retrata a festa de aniversário da avó de Bobby, em que o irmão mais velho, Ed Griffth, carrega uma bolsa e começa a encenar satiricamente a performance do gênero feminino. Nesse momento, Ed é retalhado primeiro pela mãe e logo em seguida pela avó, que diz que para ela "todos os veados deveriam ser enfileirados e mortos". A família ri, mas Bobby sente-se incomodado.

Consideramos essa cena representativa para discutirmos a natureza de um discurso religioso ortodoxo, e a partir do qual essa família organiza as suas relações. Para analisarmos esse momento no contexto do filme, nos referenciamos no discurso teológico de Cornelius Van Til, uma importante referência noevangelicalismoamericano conservador. Para ele, ser cristão é uma condição de natureza ontológica. Crer em Deus, em Jesus e na Bíblia é um dado inerente à humanidade. Fundamental para a compreensão do pensamento vantiliano é a apologética do teólogo reformado holandês Abraham Kuyper, que permeia toda a teologia de Van Til. Kuyper faz uma análise sobre o efeito do pecado para o conhecimento da verdade, na qual considera queo pecador possui uma visão de mundo corrompida. Para Van Til, assim 
como para Kuyper, existem dois sistemas de vida antagônicos que determinam a visão de mundo dos indivíduos.

Todavia, estas duas visões de mundo não são apenas perspectivas de conhecimento, mas, como já indicamos, constituem dois sistemas de vida que estão em combate mortal” (KUYPER, 2004, p. 19apud SOUZA, 2017, p. 56)

Assim, o sistema de vida secularizado, representado pelo modernismo humanista, é permeado pelo pecado. O pecador, por sua vez, não possui as qualidades ontológicas para elaborar o conhecimento verdadeiro (de Deus, da natureza ou dos seres humanos),produzindo assim, dois sistemas de vida que equivalem a dois tipos diferentes de ser humano: o crente e o incrédulo.No filme é possível identificar a presença desse embate entre dois tipos de seres humanos e dois tipos de sistemas de vida a partir da relação que se estabelece entre Mary e Bobby.

Esta dicotomia entre crente e incrédulo resulta para Van Til, assim como para Kuyper, em duas visões de mundo distintas e conflitantes, que marcam não somente as diferentes perspectivas a partir das quais diferentes homens existem e veem o mundo, mas, também, marcam aquilo a que eles conferem autoridade. 'Existem duas e apenas duas classes de homens. Existem aqueles que adoram e servem a criatura e aqueles que adoram e servem o Criador' (VAN TIL, 2003, p. 62) ". (SOUZA, 2017, p. 69).

A diferença entre o crente e o incrédulo é fundamentada, então, em duas visões de mundo absolutamente antagônicas e excludentes, de forma a impossibilitar o diálogo, isto porque, questionar esse sentido radical de crença é questionar toda a base na qual se estrutura a leitura de mundo desses indivíduos. Então, o processo de abertura ao diálogo e à alteridade de um sistema de vida opostono âmbito desse tipo específico de cosmovisão, é algo verdadeiramente complexo e difícil, tal como se pode perceber no exemplo do filme: o jovem termina por suicidar-se.

Importante notar que esta concepção de dois sistemas de vida com suas respectivas visões de mundo antagônicas e incomunicáveis, é qualificada por Van Til mesmo como sendo uma "interpretação absolutamente abrangente da experiência humana", a qual este teólogo chama de biocosmovisão cristã (SOUZA, 2017, p. 72)

Observa-se que, na raiz desse discurso, existem posições valorativas binárias. Os conceitos de sistema de vida, biocosmovisão cristã, e crente e incrédulo desenvolvidos por Van Til são orientados para que se tenha como verdadeiro e indubitável somente um dos 
polos opostos. Todo seu método, denominado por ele de pressuposicionalista ${ }^{33}$, segue uma lógica binária que opera um conflito indissociável de valores irreconciliáveis.

Para o teólogo de Westminster, os incrédulos têm a sua compreensão de mundo distorcida, pois colocam como fím último desta compreensão a própria subjetividade, baseada na autonomia e na liberdade da criatura em relação ao criador, realizando assim, uma interpretação da Escritura a partir do conjunto de valores ditos mundanos e não de valores cristãos. (SOUZA, 2017, p. 68)

Para ele, o Deus da Escritura deve ser considerado como o único e verdadeiro pressuposto para todo conhecimento e comportamento do indivíduo em todas as esferas da vida social. Assim, é necessário recusar toda interpretação da realidade que não seja à luz da doutrina cristã reformada. O que o pensamento de Van Til revela são elementos que apontam para uma dimensão ideológica e de poder implícitos em seu discurso (SOUZA, 2017).

Na cena 2,após descobrir sobre a homossexualidade de Bobby, Mary passa a submetêlo a uma série de "tratamentos" com o objetivo de "curá-lo". Primeiro, a mãe coloca, logo pela manhã, a pregação de um pastor que recita a Bíblia e,depois disso, espalha lembretes pela casa, com citações bíblicas para lembrar Bobby da condenação de seu pecado e da promessa de redenção divina. A terceira etapa do processo consistiu em submetero filho a exaustivas sessões de terapia e auxílio psicológico cristão, o que pelo filme se tornaram momentos de desconforto para Bobby.

Percebe-se na atitude de Mary Griffith elementos centrais do pensamento de Van Til, tais como o estatuto da Escritura e a sua centralidade para o sistema de vida cristão. Para Van Til, a Bíblia é primordial e fala de tudo, seja diretamente ou por implicação; ela é portadora da verdade universal, absoluta, ampla e irrestrita.

Para Van Til, o cristianismo reformado, fundado na literalidade e na inerrância da Escritura, é a única fonte de orientações verdadeiras para o entendimento do mundo. Isto é, a fé em Deus é entendida como o pressuposto de toda forma de conhecimento humano que se pretenda verdadeiro.

Sem a luz do cristianismo é pouco possível para o homem ter uma visão correta a respeito de si mesmo e do mundo, assim como ter uma visão verdadeira de Deus. Por causa do pecado o homem está cego com relação à verdade, onde quer que ela apareça. E a verdade é uma, qual seja, que o homem não pode conhecer

\footnotetext{
${ }^{33}$ Pressuposicionalista: A apologética pressuposicionalista é o método teológico que orienta o pensamento de Van Til. O que significa que o autor fundamenta os seus argumentos por pressuposições, ou seja, ele "ressalta os princípios epistemológicos e metafísicos que sustentam e controlam cada método" (SOUZA, 2017, p. 58). Dessa forma, seu método tem como pressuposição a verdade do teísmo cristão que se fundamenta na visão do Deus absoluto. Assim, a metodologia cristã se baseia em pressuposições contrárias às da metodologia não cristã.
} 
verdadeiramente a si mesmo sem que conheça verdadeiramente a Deus. (VAN TIL, 2008, p. 96apud SOUZA, 2017, p. 64)

O filme em questão é revelador desse entendimento de uma cosmovisão dualista. Bobby encontra, de um lado, uma família religiosa conservadora, fiel ao princípio protestante de literalidade e inerência da Bíblia e fechada em sua própria cosmovisão. Nesta, é praticamente impossível o diálogo com a diversidade de visões de mundo e a entrada de qualquer entendimento que não o cristão reformado ortodoxo.Do outro, o mundo secularizado, plural e diverso, com uma abertura para leituras, possibilidades e complexidades — inclusive da interpretação da Escritura cristã -, que se colocam em conflito com a sua perspectiva familiar de origem.

\section{“Sério mãe, é assim que o amor se parece?": a cosmovisão cristã ortodoxa acima de tudo, um ser humano contra o outro.}

O discurso moral da cosmovisão religiosa cristã se configura, como proposto no pensamento de Van Till, em uma lógica binária que implica no entendimento e na normatização de práticas e ações comportamentais dualizadas. A ideia de sistemas de vida e dois tipos de indivíduos — crente e incrédulo — reflete-se também na dicotomia dos papéis e das relações de gênero e de poder que contribuem para o assujeitamento e reforço de estigmas que promovem violência contra determinados grupos sociais (CASTRO, 2014). O regime heterossexista, no qual se insere o pressuposto da heterossexualidade como natural, estabelecendo assim um modelo de heteronormatividade, é tido como inerente ao sistema de vida cristão. Logo, investe e se impõe, sobretudo,por meio de violências simbólicas (nos procedimentos de "cura gay", que patologizam a homossexualidade, por exemplo; no rechaço aos gays que não interpretam o papel da masculinidade heteronormativa; no uso corriqueiro de expressões depreciativas como "bicha" ou "viadinho" para classificar indivíduos homossexuais, entre outros) e físicas (agressões contra grupos LGBTs, massacres como o ocorrido em Orlando, nos Estados Unidos em $2016^{34}$, perseguições a travestis,etc.)a todo e qualquer comportamento sexual ou de gênero que se oponha a esse entendimento heteronormativo, tido como o único possível e verdadeiro, incompatível, por sua vez, com o sistema de vida não cristão, impuro e pecador.Essa concepção não só contribui para o estigma que sofrem os indivíduos homossexuais, como também inaugura o entendimento de que essa

\footnotetext{
${ }^{34}$ Disponível em: <http://g1.globo.com/mundo/noticia/2016/06/policia-diz-que-ataque-em-boate-nos-euadeixou-50-mortos.html>. Acesso em 01 de novembro de 2018
} 
categoria tida como subversiva é inimiga e, portanto, deve ser excluída, combatida, quando não eliminada. Outra possibilidade observada no filme, é a busca de conformação desses sujeitos e seus corpos ao modelo heteronormativo característico do sistema de vida cristão, superando assim, a condição de pecadores na qual esses sujeitos estavam imersos.

$\mathrm{Na}$ terceira cena selecionada para este estudo, os amigos de Bobby vão buscá-lo em sua casa. Incomodada, Mary discute com o filho, afirmando que o amava e que só queria seu bem. Bobby termina a cena com a pergunta substancial: "sério mãe, é assim que o amor se parece?". No pensamento vantiliano o mundo desencantado, separado de Deus e centrado no homem, é impuro, logo, tido como pecado. O pecador, por não possuir capacidades ontológicas de elaborar conhecimento verdadeiro (esta habilidade só cabe ao crente), é dotado apenas de visões corrompidas. $\mathrm{O}$ estigma da homossexualidade homogênea e categórica traça um entendimento moral e prático irrevogável de distinção e rotulação dos indivíduos. Nessa perspectiva, Bobby não é o filho de Mary, não é sujeito, não é pessoa, mas é uma categoria definida e oposta ao padrão heterossexual normativo, tido como "verdadeiro" e "absoluto" por aquela família, logo, parte de um sistema de vida contrário.

Essa divisão impede o reconhecimento da alteridade e trata quaisquer outros discursos, sejam eles não-religiosos, ou mesmode outras tradições e denominações religiosas que não a cristã reformada, como falsos e, consequentemente,condenáveis e combatíveis.Práticas em desacordo com o ethos social daquele determinado grupo cristão são tratadas como expressões de impureza, e esse discurso recai inclusive e principalmente sobre o ator da prática.Nesse sentido, se inserido no âmbito desse mesmo grupo,esse indivíduo torna-se condenado pela própria comunidade o que, por sua vez, não se dissocia da própria noção que o indivíduo religioso passa a atribuir a si mesmo, que é a de impuro. Quando o apontam como praticante de pecado, o indivíduo religioso pode também passar a enxergarasi próprio como pecador. Afinal, a legitimação desse discurso vantiliano no âmbito binário dos papéis de gênero e da própria sexualidade não se dá apenas pela externalização e performance de gênero em uma esfera social no âmbito das relações de parentesco ou de família, mas, e principalmente, ela acontece porque é internalizada (FOULCAULT, 2008). Nesse sentido, a experiência religiosa acontece justamente na subjetividade do discurso religioso que, por sua vez, envolve um sistema de crenças e certos modos de viver e agir.

É o que se vê na cena 4, em que Bobby pela primeira vez vai a uma boate na intenção de explorar sua sexualidade. A luz escura, a música pesada e tensa com o enfoque lateral da câmera atrelados à expressão de desconforto do garoto durante um beijo, culminam na ação seguinte quando o parceiro comenta "uau, você é realmente lindo. Nunca te vi antes. Posso 
pegar seu número? ". Bobby, visivelmente abalado e em crise balbucia um "Não" ríspido, seguindo para a saída da boate, onde depara-se com uma placa de apoio à comunidade GLS da Igreja da Comunidade Metropolitana. Embora na cena não apareça a figura da mãe ou de ninguém da sua família, o desconforto e o conflito religioso são elementos marcantes, na qual Bobby apresenta-se tenso, pressionado e, sobretudo, culpado, dividido entre o desejo e o prazer da experiência que acabara de ter e a carga subjetiva doutrinária religiosa e familiar que carrega consigo. Aliás, a igreja inclusiva entra justamente como uma resposta ao conflito interno que Bobby sofre naquele momento: possibilita ao garoto, pela primeira vez, o diálogo e ressignificação da pertença religiosa e, consequentemente, um possível fim do conflito internovivenciado pela compreensão dualista de mundo e de ser humano.Todavia, com o desenrolar d da trama, esta resposta ainda assim não fora suficiente.

\section{O Soltar Do Pano: Uma Abertura Ao Diálogo}

Na cena 5, temos o pós-enterro de Bobby, no qual ocorre um confronto de visões de mundo: de um lado, a prima de Bobby, acusando Mary de "cegueira", de outro Mary lavando as mãos compulsivamente (o que representa a repulsa que sentiu ao cumprimento de David, namorado de Bobby), acusando-a de manter o garoto em algo fora da tradição religiosa na qual fora educado.Esse gesto de lavar as mãos, por um lado, revela a ideia de homossexualidade como doença contagiosa e, por outro, a própria noção de que o crente jamais deve se deixar contaminar pelo sistema de vida do incrédulo. Ao final, a cena aponta ao primeiro indício da abertura ao diálogo, Mary para de lavar as mãos, põe-se aos prantos e solta o pano.

Em um sentido geral, o "soltar do pano" pode ser entendido como o desatar os nós do conservadorismo que apertara com tanta força até então, levando-a a recusar o próprio filho e vendo-o vítima de suicídio pelo sofrimento da não aceitação. Essa discussão indicaum embate que poderia culminar em duas possibilidades: por um lado, questionar a fé cega pode levar a um enclave ainda mais ortodoxo,por outro, a abertura a novos significados pode levar a um entendimento diverso da própria pertença religiosa, tão profundo e genuíno quanto a pertença anterior, indicando uma ruptura, mas não o abandono de uma reserva de sentido religiosa. Um dado fundamental para compreender essa abertura, aqui, foi o acesso da mãe aos escritos pessoais do diário do filho, que trazem as perspectivas interpretativas dele sobre a própria sexualidade e a relação dessa com a pertença religiosa. Aqui há um momento extremamente significativo: o acesso a essa narrativa e aos meandros da subjetividade de Bobby dá à mãe a 
chance de reconhecer a alteridade do filho, e é esse reconhecimento que a leva a questionar a própria interpretação da escritura. É possível notar que em suas cartas, Bobby levanta questões sobre a bondade de Deus, por exemplo, o que o leva a colocar um xeque a interpretação de um Deus atroz e punitivo. Contudo, mais do que uma questão de interpretação das Escrituras, é a questão da alteridade que se coloca como substancial, é o reconhecer o outro como um igual, é isso quede fato a abre para o diálogo. É a partir deste ponto que Mary procura novamente a igreja progressista, dessa vez aberta a uma nova leitura da escritura para ter ressignificada e reconsolidada a sua reserva de sentido religiosa. O que a leva a esse novo lugar não é a simples leitura da escritura, mas sim, o acesso à subjetividade do filho.

Ao compreender que uma interpretação absoluta e final da Bíblia não a permitiu enxergar a realidade na sua pluralidade, a mãe de Bobby percebe que existem várias maneiras de interpretar o mundo, iniciando assim um processo de aceitação do lugar de seu filho a partir da orientação sexual que o definia. É o que retrata a cena 6 , onde acontece a discussão teológica entre o pastor progressista da Igreja da Comunidade Metropolitana e Mary. A mãe de Bobby discute sobre a homossexualidade ser ou não ser um pecado de acordo com a leitura do Antigo Testamento proposta pelo ministro religioso daquela igreja. Ambos discutem acerca do episódio bíblico em que as cidades de Sodoma e Gomorra foram destruídas. Muitas pessoas acreditam que a destruição fora por conta da homossexualidade, mas o referido pastor mostra um entendimento de que o pecado fora a ganância.Eles entram num impasse interpretativo do texto sagrado cristão a partir do choque de duas leituras: de um lado, o conservadorismo da mulher e do outro a reinterpretação dialogal da Igreja Metropolitana. "Você acha que podemos interpretar a bíblia da maneira que acharmos conveniente?", questiona a religiosa. O pastor, por sua vez, argumenta que não, mas que a Bíblia é interpretada por homens mortais que são limitados pelos reflexos do seu próprio tempo, o que coloca em suspenso a ideia ortodoxa de inerrância e infalibilidade da escritura, tão aguerridamente cultivada por Mary Griffith.

Em geral, o problema enfrentado nesse momento do filme recorda um documento do Parlamento das Religiões Mundiais, na Conferência de Chicago sobre o diálogo:

Reiteradas vezes, e em diversos lugares deste mundo, observamos que líderes e adeptos de religiões instigam à agressão, ao fanatismo, ao ódio e à xenofobia; e inspiram e legitimam até mesmo confrontos sangrentos e marcados pela violência. Usurpa-se a religião para fins meramente voltados à conquista do poder político, até o extremo da guerra. Isso nos causa grande repugnância. (Os princípios de uma 
Ética Mundial - DECLARAÇÃO DE ÉTICA MUNDIAL - PARLAMENTO DAS RELIGIÕES MUNDIAIS, 4 de setembro de 1993, Chicago).

O filme revela o momento em que a mãe de Bobby compreende essa dinâmica intrínseca a perspectivas religiosas ortodoxas e se abre ao diálogo, ao reconhecimento de que existe algo que lhe é externo e diferente, e esse diferente não precisa representar uma ameaça à sua cosmovisão ao sentido que dá à vida.

$\mathrm{Na}$ sequência, a sétima cena retrata o momento que entendemos ser o mais relevantepara a discussão aqui proposta: Mary tem o despertar e chora pela morte trágica do filho. Ela se culpa por ter parte da responsabilidade no julgamento e condenação do "pecado da homossexualidade", ideia que levou o jovem Bobby ao suicídio.Esse momento é representativo da síntese do processo que Mary vinha enfrentando, é o momento no qual ela aceita a nova interpretação e aprofunda numa religiosidade igualmente cristã, porém, mais aberta e dialogal.

\section{Considerações Finais}

Conforme proposto, o presente estudo acerca da construção histórico-social dos corpos no âmbito de um discurso moral, a partir da análise do filme "Orações para Bobby”, procurou evidenciar que tal discurso encontra fundamento em perspectivas teológicas tais como a de Cornelius Van Til, caracterizada pela concepção da existência de dois sistemas de vida antagônicos que determinam a visão de mundo dos indivíduos A tal concepção de homem e de mundo subjaz a dualidade entre crente e incrédulo, pecador e não pecador, pura e impuro, condensando assim, uma série de noções binárias, excludentes e categóricas, que funcionam como marcadores sociais impostos aos sujeitos e seus corpos. Nocaso dos indivíduos homossexuais masculinos que adotam esse tipo de cosmovisão, essas noções se impõem, sobretudo,por meio de violências sutis que servem de coesão e coerção social cotidiana.

Observa-se que é justamente esse tipo de discurso religioso que fundamenta o ideário da família Griffth e sustenta os valores essenciais de sentido de vida que esses indivíduos atribuem a si e aos outros. Pela narrativa expressa no filme é possível perceber queesse sentido de vida e mundo é determinado por certo tipo de cosmovisão que se entende como absoluta, superior e última, não permitindo assim, quaisquer desvios. Em outras palavras, não existe qualquer possibilidade de interpretação e verdade para além do que se propõe no sistema de vida cristão, e todo aquele que o faça fora dessas bases é rigorosamente perseguido. 
Orações para Bobby consiste em uma boa representação de como se opera na vida cotidiana de indivíduos crentes um discurso fundamentadoem um tipo de cosmovisão cristã conservadora e o consequenteembate entre tradições e interpretações de mundo antagônicas. No filme, o suicídio do jovem Bobby é consequência extrema da impossibilidade de abertura ao diálogo com essa cosmovisão tradicional da família. Socialmente, Bobby nunca abandonou a tradição religiosa a qual pertencia, ao mesmo tempo em que não se sentia aceito pela mesma e pela sua própria família. Todas as suas experiências e conflitos internos se deram por meio de processos de violência simbólica (de não aceitação da família, de patologização da homossexualidade etc.) respaldada em compreensão literale não historicizada da Bíblia, que coloca a homossexualidade como pecado e, por isso, condenável.A violência simbólica impingida a Bobby no início do filme se consolida como violência física no ato último do suicídio. Importante destacar que o suicídio não fora um ato solitário, muito menos desconectado do contexto familiar e social dos Griffth. Quando a mãe afirma "eu matei meu filho", esse aspecto se mostra ainda mais evidente.

O último enfoque é destinado justamente à Mary, uma vez que ela é a chave da análise no processo de ressignificação e abertura ao diálogo, após a morte do filho. A mãe de Bobby em momento algum abandona sua fé no cristianismo protestante, mas quando entende as bases sobre as quais se erigiu a sua crença ecompreende a dor que o filho sentiu por ser considerado como pecador e indigno do amor de Deus e da família, passa a transitar entre duas interpretações da Escritura, o que gera um novo entendimento religioso e, consequentemente, uma nova postura e comportamento social. Mary torna-se membro da PFLAG e uma importante ativista e militante pelos direitos LGBTs. Tal movimento que era impensável no início do filme, e só se tornou possível pelo entendimento não da perspectiva religiosa conservadora na qual apoiara sua compreensão de vida e mundo ao longo da vida, e a abertura a novas interpretações que permitissem a manutenção do cristianismo como reserva de sentido religiosa da vida, porém, em diálogo com a diversidade de sistemas de vida, de sujeitos e seus corpos. Mary Griffth passa a enxergar o mundo que a cerca com novas lentes através da ressignificação de sua fé, da alteridade e do acolhimento e reconhecimento da pluralidade e da diversidade.

\section{REFERÊNCIAS}

BOURDIEU, Pierre. Sobre o Estado: Cursos no Collège de France (1989-92) / Pierre Bourdieu; [ediçãoestabelecida por Patrick Champagne... [et al.]]; tradução Rosa Freire d'Aguiar - 1a ed. - São Paulo: Companhia das Letras, 2014 
CASTRO, Roney Polato de. Experiência e constituição de sujeitos docentes: relações de gênero, sexualidades e formação em Pedagogia. Tese de doutorado, acervo da biblioteca da Universidade Federal de Juiz de Fora: Juiz de Fora, 2014. P. 189-225.

CONNELL, Raewyn; PEARSE, Rebecca. Gênero: uma perspectiva global. Moschkovich, Marília. São Paulo: nVersos, 2015.

DECLARAÇÃO DO PARLAMENTO DAS RELIGIÕES DO MUNDO:A história de um dos documentos mais importantes do final do século $\mathrm{XX}$, contada por um de seus principais criadores.Disponível em:

$<$ http://www.pucsp.br/ecopolitica/documentos/cultura_da_paz/docs/Hans_Kung_DECLARACAO_PA RLAMENTO RELIGIOES MUNDO.pdf> Acesso em: 07 out. 2018

FONTES, J. B. O corpo e sua sombra [Prefácio à segunda edição]. In C. L. Soares (Org.), Corpo e história ( $3^{\mathrm{a}}$ ed., s.p.). Campinas, SP: Autores Associados, 2006

FOUCAULT, M.Nascimento da biopolítica: curso dado no Collège de France (1078 1979) (E. Brandão, Trad.). São Paulo: Martins Fontes,2008

LOURO, Guacira Lopes. Pedagogias da sexualidade. In: O Corpo Educado. $2^{\mathrm{a}}$ edição. Belo Horizonte: Autêntica, 2000.

MÉLlO, Ricardo Pimentel. Corpos, heteronormatividade e performances híbridas. Revista Psicologia \& Sociedade, n. 24(1), p.197-207, 2012. Disponível em: $<$ http://www.scielo.br/pdf/psoc/v24n1/22.pdf $>$ Acesso em: 10 de setembro de 2018

NUNES, S. A. O corpo do diabo entre a cruz e a caldeirinha: um estudo sobre a mulher, o masoquismo e a feminilidade. Rio de Janeiro: Civilização Brasileira, 2000.

PIEPER, Frederico. Religião e Cinema. São Paulo: Fonte Editorial, 2015. 229p.

SANTOS, Daniel Kerry dos. As produções discursivas sobre a homossexualidade e a construção da homofobia: problematizações necessárias à psicologia. Revista EPOS; Rio de Janeiro: Rio de Janeiro, Vol.4, $\mathrm{n}^{\mathrm{o}}$ 1, jan-jun de 2013. Disponível em $<$ http://pepsic.bvsalud.org/pdf/epos/v4n1/07.pdf> Acesso em: 29 de setembro de 2018.

SOUZA, Andréa Silveira de. O Pensamento de Conerlius Van Til: as bases teológicas dos reformistas e reconstrucionistas. In: O legado fundamentalista do Seminário Teológico de Westminster: reformistas $\mathbf{x}$ reconstrucionistas no espaço público americano. Tese de doutorado, 2017

TOCCHETTO, Gabriel Zanatta. A Virada Hermenêutica. In: A arte de fazer ciência: problematizar, pesquisar, publicar. Disponível em: $<$ https://www.imed.edu.br/Uploads/micimed2014 submission 6.pdf $>$ Acesso em: 03 de outubro de 2018.

VASCONCELLOS, Maria Drosila. Pierre Bourdieu: a herança sociológica. Educação \& Sociedade, ano XXIII, no 78, Abril/2002 


\title{
Liberdade para quem? As consequências da instrumentalização conservadora do conceito de liberdade religiosa nos Estados Unidos
}

\author{
Freedom for whom? The consequences of the conservative instrumentalization of the concept \\ of religious freedom in the United States
}

\author{
Juliana de Santana Oliosi ${ }^{35}$ \\ juliana.de.santana@hotmail.com
}

Resumo: Esse artigo pretende demonstrar a instrumentalização contemporânea do discurso pela defesa da liberdade religiosa na política dos Estados Unidos e os impactos relativos aos direitos das mulheres e dos LGBT. O argumento central é que o conceito de liberdade religiosa nos Estados Unidos tem sido reformulado por grupos conservadores como uma estratégia eficaz para o alcance dos seus objetivos. Além disso, a posição hegemônica desse país no campo internacional facilita a difusão da abordagem discursiva da liberdade religiosa para a arena global como algo natural, geral e universal. Para entender esse fenômeno, a lente teórica adotada vem da perspectiva dos estudos de Gênero, Religião e Relações Internacionais.

Palavras-chave: liberdade religiosa; gênero; religião; política internacional

\begin{abstract}
This article aims to demonstrate the contemporary instrumentalization of the discourse for the defense of the religious freedom in the politics of the United States and the impacts related to the rights of the women and the LGBT. The central argument is that the concept of religious freedom in the United States has been reformulated by conservative groups as an effective strategy for achieving their goals. Moreover, the hegemonic position of this country in the international field facilitates the diffusion of the discursive approach of religious freedom to the global arena as something natural, general and universal. To understand this phenomenon, the theoretical lens adopted comes from the perspective of the studies of Gender, Religion and International Relations.
\end{abstract}

Keywords: religious freedom; gender; religion; international politics;

\section{Introdução}

Liberdade é um termo carregado de conotações múltiplas, capazes de provocar reações intensas nas pessoas. Especialmente em sociedades ocidentais, democráticas e liberais, o ideal da liberdade assume contornos tão complexosquanto abstratos. Por isso, a liberdade se desdobra; é preciso tratá-la no plural. Nesse contexto, esse artigo busca discutir a liberdade religiosa. Através da perspectiva dos estudos de Gênero, Religião e Relações Internacionais, tratarei da instrumentalização do discurso da liberdade religiosa nas políticas dos Estados Unidos referentes aos direitos das mulheres e dos LGBT.

\footnotetext{
${ }^{35}$ Mestranda em Ciências da Religião na Universidade Metodista de São Paulo (UMESP). Bacharela em Relações Internacionais pela Pontifícia Universidade Católica do Rio de Janeiro (PUC-Rio).
} 
O caso estadunidense foi escolhido para análise por dois motivos principais: o amplo desenvolvimento de políticas (internacionais e nacionais) pela liberdade religiosa que há nesse país; e a exportação desse tipo de política. Sobre isso, Elizabeth Hurd explica:

\begin{abstract}
Dizem que os americanos inventaram e aperfeiçoaram a liberdade religiosa. Está pronto para exportação. E nós estamos exportando. Um número crescente de atores está promovendo a liberdade religiosa além das fronteiras do Estado. Alguns são americanos, mas muitos não são. Alguns são patrocinados pelo Estado, mas outros não são. As garantias legais de liberdade religiosa são incorporadas em acordos comerciais, em pacotes de ajuda e em projetos humanitários. Diplomatas são ensinados a persuadir seus colegas a salvaguardar a liberdade religiosa. Os acordos estabelecidos na política externa estão formalizando sua promoção (HURD, 2014, p. 225). ${ }^{36}$
\end{abstract}

O contexto dos Estados Unidos não se restringe a este país, sendo inúmeras vezes exportado para a arena global como algo natural, geral e universal. No contexto protestante e evangélico, a influência desse país se destaca também pela propagação missionária dos valores religiosos - também considerados gerais e universais. Por isso, ter um olhar global ao estudar esse assunto é uma estratégia interessante para compreender o fenômeno da instrumentalização do discurso da liberdade religiosa em outras regiões.

Elizabeth Castelli (2005, p. 322), aponta que o movimento estadunidense de ação política e solidariedade internacional é fundamentado em questões da identidade deste país, como o "americanismo" e a ideia de uma excepcionalidade nacional, mas que também há dois pontos relevantes (e interessantes nesta análise): os ideais liberais de liberdade e tolerância, e a linguagem e a autoridade dos direitos humanos - que são propagados como internacionais e universais.

Cada vez mais espalha-se a ideia de que a liberdade religiosa estaria ameaçada - um fenômeno discursivo visto não só nos Estados Unidos, mas também no Brasil. Isso ocorre através da redefinição da própria noção de liberdade religiosa, que passou a ser debatida e definida como uma ferramenta de propagação de preconceito.

Marie Gayte (2016, p. 76) aponta que a Igreja Católica e as Igrejas Evangélicas Protestantes consideram que a liberdade religiosa está ameaçada nos Estados Unidos. Esse entendimento não é novo; contudo, o debate tem sido acirrado cada vez mais, principalmente por causa da legalização do casamento gay a nível federal (em junho de 2015) e de reformas

\footnotetext{
${ }^{36}$ Texto original em inglês: "Americans, we are told, invented and perfected religious freedom. It is ready for export. And exporting it we are. A rapidly escalating number of actors are promoting religious freedom across state boundaries. Some are American, but many are not. Some are state-sponsored, but others are not. Legal guarantees of religious freedom are embedded as riders in trade agreements, in aid packages and in humanitarian projects. Diplomats are taught how to persuade their counterparts to safeguard religious freedom. Foreign policy establishments are formalising its promotion".
} 
almejadas pelo ex-presidente Barack Obama que incluiriam a obrigação legal de empregadores arcarem com os custos de contracepção de seus funcionários e funcionárias.

Avanços referentes aos direitos de reprodução e da comunidade LGBT são abordados em enquadramentos que os colocam como afrontas à liberdade de religião, e consequentemente contrários à Primeira Emenda. Como reação a isso, há uma inversão do discurso: ações e ideias antes entendidas como preconceito contra mulheres e homossexuais passam a ser reformuladas em enquadramentos de preconceito e opressão contra grupos religiosos - uma estratégia que tem se mostrado eficaz. Organizações religiosas têm sido mobilizadas para retomar seu destaque na esfera pública e pautar esse debate de acordo com interesses conservadores. Nas palavras de Gayte:

\footnotetext{
O uso da defesa da liberdade religiosa, no entanto, tornou-se sem precedentes na última década, ao ponto de agora encarnar a luta contra a contracepção, o aborto e o casamento gay. Em um contexto que se tornou favorável para os direitos de homossexuais e mulheres, vários membros da direita cristã estão tentando acreditar que, ao conceder-lhes direitos, são os direitos dos cristãos que são minados (GAYTE, 2016, p. 77).
}

A própria escolha do termo liberdade religiosa reflete o centro da argumentação conservadora desses grupos: líderes evangélicos, como Chuck Colson e o pastor Rick Warren, rejeitam o uso do termo liberdade de culto, pois acreditam que isso limitaria o conceito às práticas religiosas na duração de um culto, por exemplo (que ocupa poucas horas por semana); a religião aqui é entendida não só como momentos rituais, mas como algo que preenche e pauta todos os momentos e todas as ações da vida dos crentes (GAYTE, 2016, p. 79). Ou seja: a religião não corresponde apenas à esfera privada dos sujeitos, mas também deveria ser vivida na esfera pública.

O foco na defesa da liberdade religiosa enquanto um direito fundamental também tem outra vantagem importante - que é o ponto de virada da instrumentalização discursiva do conceito: o alcance do discurso é ampliado para além do público cristão. Apesar do públicoalvo tradicional ser os indivíduos religiosos conservadores, outros públicos podem ser alcançados, como os liberais (a favor da diminuição do papel do Estado na sociedade) e grupos sensíveis a argumentação de que ameaçar a liberdade de religião equivale a ameaçar os direitos civis.

Marie Gayte (2016, p. 80) salienta que a sociedade vive tempos onde não se pode mais tratar de assuntos como direitos à contracepção como problemas de moralidade ou de legalidade. $\mathrm{O}$ enquadramento na esfera dos direitos fundamentais é mais facilmente acolhido e 
difundido no mundo contemporâneo. Tratar de temas como contracepção e casamento gay na chave interpretativa da moralidade pode facilmente ser entendido como intolerância.

\begin{abstract}
Ao apresentar a questão em termos de violação dos direitos civis, especialmente da liberdade religiosa, os membros dos direitos cristãos apelam para valores considerados fundamentais pelos americanos e consagrados na Primeira Emenda da Constituição, o que coloca seus oponentes em uma situação delicada. Neste contexto de uma campanha baseada em direitos, os direitos cristãos não hesitam em comparar sua luta pela liberdade religiosa com o movimento pelos direitos civis liderado por afro-americanos nos anos 50 e 60, e com a luta pela abolição da escravidão no século XIX, retratando o governo e os ativistas da liberdade reprodutiva e do casamento entre pessoas do mesmo sexo como os opressores de outrora (GAYTE, 2016, p. 80).
\end{abstract}

Nesse enquadramento, a interpretação tradicional de que cidadãos e cidadãs devem obedecer às leis passa a ser reformulado com uma ressalva: dependendo da lei há um estímulo à "desobediência civil". Leis que sejam consideradas contrárias aos valores religiosos de pessoas, grupos, ou mesmo empresas, são consideradas leis que podem e devem ser combatidas e desobedecidas - como negar a execução de um abordo ou a celebração de um casamento homossexual quando garantidos por lei, por exemplo.

Marie Gayte(2016, p. 81 - 82) destaca que um dos sinais mais notáveis da renovação da campanha pela liberdade religiosa - e seus impactos duradouros na vida pública - é o desenvolvimento de uma espécie de "novo ecumenismo", impensável a cerca de uma década. Evangélicos, católicos e mórmons se unem em torno dos objetivos conservadores da direita religiosa. Não é uma união doutrinária, nem significa exatamente a superação dessas diferenças. Contudo, os objetivos políticos em comum e a influência que esses grupos somados alcançam passaram a ter mais peso nessas relações, levando a um ecumenismo de conveniência, onde o destaque desses grupos recai sobre os princípios em comum e os objetivos que querem na dinâmica da vida pública.

É importante enfatizar que o debate pela defesa da liberdade religiosa é pautado de maneira que não engloba apenas igrejas e grupos religiosos no geral, mas envolve outros agentes, como empresas e ONGs, por exemplo.

\footnotetext{
A liberdade religiosa torna-se assim o direito de não se submeter às injunções de uma sociedade cujas evoluções rejeitam. É o direito de discriminar pessoas do mesmo sexo recusando-se a servir como fornecedor ou fotógrafo no casamento. É o direito de recusar ao cônjuge de um homossexual os mesmos direitos que o seu cônjuge (pensão de viuvez, cobertura de saúde), é o direito de fazer as mulheres pagarem pela sua contracepção. É, portanto, uma questão de viver de acordo com as convicções religiosas em todos os aspectos da existência, pública e privada, sem qualquer impedimento. Além disso, a liberdade religiosa, de acordo com os direitos cristãos, não deve ser confinada a igrejas ou indivíduos: empresas, associadas ou não
} 
a uma igreja, com fins lucrativos ou não, devem poder invocá-lapara recusar-se a obedecer às leis que elas consideram prejudiciais (GAYTE, 2016, p. 85).

Marie Gayte destaca que, na prática, isso equivale a permitir que qualquer tipo de empresa possa escapar das leis contra descriminações - principalmente contra mulheres e homossexuais. Isso mostra de maneira clara uma lógica de inversão de minoria e maioria: a empreitada ecumênica utiliza leis anteriormente voltadas para minorias religiosas como base para alcançar os objetivos políticos de grupos religiosos e conservadores majoritários (GAYTE, 2016, p. 87).

\section{Complexo De Perseguição E Suas Origens Históricas}

A mobilização política do discurso de defesa da liberdade religiosa nos Estados Unidos busca, de maneira abrangente, silenciar o debate político e as constantes críticas direcionadas à direita conservadora. Dessa forma, qualquer oposição aos objetivos desses grupos é caracterizada como antirreligiosidade e perseguição (CASTELLI, 2007b, p. 154). Como visto através do trabalho de Marie Gayte, essa tendência não é exatamente nova, embora assuma contornos críticos e amplificados nos últimos quinze anos.

Ao analisar esse fenômeno, Elizabeth Castelli (2007b, p. 155 - 156) aprofunda ainda mais o entendimento sobre o tema ao identificar as possíveis raízes históricas que explicariam porque esse discurso invertido de opressão aos direitos religiosos encontra tanta receptividade no meio cristão. Segundo a pesquisadora, essa retórica religiosa consegue operar com eficácia impactos significativos no campo político e ideológico por causa da sua capacidade de mobilização de fiéis em torno do assunto (a liberdade religiosa) através da repetição histórica da figura de mártir - relacionada com a ideia de que a comunidade religiosa cristã estadunidense está constantemente em perigo ao longo da história. Nesse processo, Castelli identifica que há no país uma espécie de "complexo de perseguição".

A religião cristã é fundada em um arquétipo de perseguição política e religiosa: a execução de Jesus pelo governo romano. As bases do discurso de perseguição também estão fundamentadas nos relatos bíblicos referentes ao início das primeiras comunidades cristãs, como exemplificado nos evangelhos e nas cartas do Novo testamento. Castelli destaca exemplos recorrentes:

"Bem-aventurados os que são perseguidos por causa da justiça", diz Jesus no Sermão da Montanha, "pois deles é o reino dos céus". "Bendito és quando os homens te insultam, e te perseguem e profanam todos os tipos de mal contra ti 
falsamente por minha conta "(Mateus 5.10-11). Enquanto isso, no Evangelho de João, Jesus adverte seus alunos com estas palavras: "Lembrem-se das palavras que eu disse a vocês: 'Um servo não é maior que seu mestre.' Se eles me perseguiram, eles te perseguirão" (João 15.20). Décadas antes desses evangelhos serem escritos, o pregador itinerante e missionário Paulo escreveu à jovem comunidade cristã em Corinto: "Por causa de Cristo, portanto, estou contente com fraquezas, insultos, dificuldades, perseguições e calamidades; porque quando estou fraco, então sou forte"(2 Coríntios 12.10). (CASTELLI, 2007b, p. 161)

Ao avançar na história do cristianismo, é possível perceber uma mudança na interpretação dos conceitos de sofrimento e perseguição. Se antes ser perseguido pela fé era ser bendito, a retórica se transforma lentamente e passa a colocar perseguidos no lugar de perseguidores, em momentos históricos polêmicos e ignorados na instrumentalização contemporânea do discurso da liberdade religiosa.

Castelli exemplifica isso citando figuras históricas e relevantes da igreja cristã. Se no século II Tertuliano, pai da igreja norte-africana, ligou a experiência da perseguição à expansão da religião, ao comparar o sangue dos cristãos com a semente da igreja, no século IV a situação da igreja cristã já tinha se transformado o suficiente para que fosse possível Lactâncio escrever a obra $A$ morte dos perseguidores, onde ele narrou de maneira positiva as mortes terríveis que muitos perseguidores famosos tiveram, como imperadores e outros contemporâneos (CASTELLI, 2007b, p. 161)

$\mathrm{Na}$ era pós-constantiniana, com a dominação da linguagem do império, Castelli (2007b, p. 161 - 162) relembra que a legislação imperial cristã tratava os não-cristãos ("pagãos") que antes estavam em posição de poder como perseguidores, e isso justificaria que a igreja agora no poder proibisse suas práticas religiosas. Isso incluía a permissão para que monges praticassem atos de violência, como invadir as casas de pessoas para destruir objetos religiosos não-cristãos.

É possível encontrar um eco entre passado e presente aqui: os monges nesse caso eram considerados inocentes em seus atos "necessários" de defesa da igreja, pois agiam como mártires (testemunhas) de Cristo; da mesma maneira, os grupos religiosos estadunidenses contemporâneos também tentam se inserir nesse enquadramento, como o incentivo à “desobediência civil” mostra. Na atualidade, Castelli (2007b, p. 165) aponta que a retórica da liberdade religiosa - com a interpretação de que os direitos de cristãos e cristãs estão sendo violados - estimula uma lógica autorreferencial que se baseia na ideia de que a comunidade cristã está permanentemente envolvida em uma batalha cósmica sem fim contra "o inimigo". 


\title{
Perigos Da Instrumentalização Do Discurso Pela Liberdade Religiosa
}

O ativismo apaixonado pela defesa da liberdade religiosa como norma universal facilmente oculta os projetos políticos situados historicamente que vêm sendo implementados por Estados e autoridades globais.

\begin{abstract}
A promoção da liberdade religiosa não é a história da disseminação global progressiva de uma norma universal e de um padrão legal. Precisamos distinguir entre um estado abstrato e almejado de coexistência religiosa pacífica e a prática oficial da promoção da liberdade religiosa. Enquanto o primeiro é certamente desejável, não significa que a última realmente ajude a alcançar isso (HURD, 2014, p. $226-227)$.
\end{abstract}

Os perigos da liberdade religiosa não estão no direito em si, mas na instrumentalização discursiva desse direito; na adoção da linguagem, dos argumentos e dos valores de direitos humanos por ativistas religiosos unidos para alcançar objetivos estratégicos próprios, através da exploração do enquadramento da universalidade dos direitos humanos.

Castelli (2007a, p. 674) aponta que, no contexto estadunidense, o apelo do discurso dos direitos humanos - e aqui especificamente da liberdade religiosa -ocorre de duas maneiras diferentes, mas complementares: o apelo à autoridade moral desses direitos, e o enquadramentos destes como derivados da autoridade divina de Deus - a despeito das raízes iluministas e seculares do conceito de direitos humanos.

Por isso, Hurd(2014, p. 234) afirma que a popularidade da ideia de liberdade religiosa não significa a vitória de uma perspectiva pacifista sobre a violência contra indivíduos; tampouco demonstra uma vitória da religião sobre o secularismo, como muitos militantes conservadores podem considerar. Mesmo com o argumento da busca pelo direito de viver a religião plenamente, em todas as esferas da vida, as ações políticas referentes a assuntos religiosos têm reforçado as linhas divisórias sociais que separam a religião da não-religião, e os crentes dos não-crentes.

Além disso, Elizabeth Hurd(2014, p. 234) alerta que essa defesa, mesmo calcada em conceitos de universalidade liberal e democrática, pode efetivamente minar o regime democrático. Isso não significa que a democracia é necessariamente secular; o risco surge porque as práticas da defesa conservadora da liberdade religiosa buscam regular - e erradicar - o potencial de desenvolvimento de minorias consideradas contrárias aos objetivos da militância. A defesa contemporânea da liberdade religiosa tem mais a ver com o jogo político 
do que com garantias efetivas de direitos para pessoas e grupos que realmente precisem desse suporte.

$\mathrm{Na}$ prática, o modelo contemporâneo de defesa da liberdade religiosa alça as autoridades religiosas a posições de poder (político, cultural e religioso) às custas das pessoas que ficam à margem, como dissidentes e pessoas não envolvidas com os modelos religiosos dominantes.

\begin{abstract}
A liberdade religiosa estrutura o campo da possibilidade religiosa e política de tal forma que os indivíduos são compelidos a fazer reivindicações políticas por motivos religiosos; isso torna a diferença religiosa mais politicamente saliente e socialmente divisível; e empodera autoridades centrais, geralmente majoritárias, às custas de dissidentes, não-crentes, minorias e pessoas que vivem nas sombras ou à margem das comunidades estabelecidas (HURD, 2014, p. 235).
\end{abstract}

Isso tem sido especialmente prejudicial para as mulheres e pessoas LGBT.Castelli alerta que se a liberdade religiosa é um direito que deriva do próprio Deus, então esse direito passa a ser superior a outras reinvindicações de direitos. Por isso, concepções superficiais de direitos humanos potencializam conflitos entre demandas de origem religiosa e demandas de grupos enquadrados como opostos a essas demandas - caso dos grupos LGBT e mulheres em busca da liberdade reprodutiva (CASTELLI, 2007a, p. 675). A retórica da liberdade religiosa tem funções performativas, proféticas e idealizadoras, funçõesque passam propositalmente despercebidas no discurso desse ativismo. Nas palavras da pesquisadora sobre esse discurso:

\footnotetext{
Eleencobre o impacto retórico da repetição insistente de que "liberdade religiosa" é um direito humano dado por Deus, insistência que torna os conteúdos da categoria e os efeitos de sua imposição fechados à discussão ou crítica, encadeados por um impulso inquietante em direção ao absolutismo. Quando os direitos humanos e a liberdade religiosa passam a ocupar todo o terreno do pensável vis-à-vis "liberdade", subjetividades não-religiosas - grupos de pessoas que se organizam sob outros tipos de identidades e reivindicam direitos contrários a alguns ensinamentos religiosos (mulheres e as minorias sexuais, mais notavelmente) - encontram-se na posição impossível de procurar fazer as suas reivindicações em bases religiosas ou não ter fundamento para falar (CASTELLI, 2007a, p. 684).
}

Essas tensões ficam evidentes nas relações que os grupos religiosos majoritários estabelecem com os governos. O Estado pode ser considerado um canal da vontade divina, ou uma instância oposta à Deus. Exemplos disso são vistos quando se compara a administração de George W. Bush com a de Barack Obama. Castelli (2007a, p. 682) afirma que a luta pela liberdade religiosa através da linguagem de direitos humanos combinava com a política externa e interna idealista de Bush. A ideia de que o estilo estadunidense de democracia é o 
ideal para todos tenta apagar diferenças no campo internacional e também no nacional - e aqui tinha amplo respaldo do governo.

O governo posterior, do presidente Barack Obama, não teve uma relação tão tranquila com o ativismo conservador pela liberdade religiosa. No campo internacional, é importante ressaltar que os ideais do americanismo e a influência (e interferência) da política externa dos Estados Unidos sempre apresenta elementos intervencionistas correspondentes ao seu papel hegemônico, em maior ou menor escala. Porém, há diferenças perceptíveis dependendo do viés do governo em exercício.

No caso do governo Obama, as tensões internas podem ser exemplificadas de maneira resumida nas políticas da área da saúde - no Obamacare. Marie Gayte (2015, p. 76) explicitou isso ao abordar as reformas que visavam imputar responsabilidade legal aos empregadores no financiamento dos custos de contracepção dos empregados e empregadas. Obama foi associado a uma militância anti-cristã. A legalização do casamento entre pessoas do mesmo sexo a nível federal é outro ponto de destaque nas tensões entre Estado e militância religiosa. Gayte cita a fala do presidente da Conferência Nacional de Liderança Cristã Hispânica, que em julho de 2015 acusou a decisão da Suprema Corte de ser um catalizador que iria marginalizar os cidadãos e cidadãs do país cuja cosmovisão de vida fosse baseada na bíblia (GAYTE, 2015, p. $76-77$ ).

Fica evidente o quanto a instrumentalização da defesa pela liberdade religiosa - com base em valores de grupos específicos - se pretende universal, e o quanto isso têm afetado minorias sexuais e os direitos das mulheres, tentando tirar esses grupos da arena de debate e minar o avanço e a manutenção de direitos já conquistados.

Nota-se o desdobramento desse projeto discursivo: ao enquadrar o casamento gay e a homossexualidade como fundamentalmente contrários à mensagem cristã, esses ativistas podem fazer a próxima virada lógica, caracterizando esforços para defender ou escorar os direitos reivindicados pelos gays como um ataque agressivo ao cristianismo [...] O ativismo gay torna-se, nesse enquadramento, uma violação da liberdade religiosa e (por implicação) um desafio à Primeira Emenda. Como consequência, o ativismo gay, nessa leitura, é inconstitucional e, portanto, essencialmente antiamericano. Esforços de gays para buscar reparação nos tribunais se tornam atos de intolerância religiosa e perseguição. Que este conjunto de reivindicações reflete uma leitura errada estratégica da Primeira Emenda, que circunscreve as ações do estado e não as ações dos cidadãos privados, é digno de nota; aqui, como em outros lugares, a Constituição funciona para esses ativistas mais como uma arma tática do que como uma fonte de princípios para organizar a vida da sociedade (CASTELLI, 2007b, p. 160). 


\section{Conclusão}

A promoção da liberdade religiosa tem sido amplamente difundida, indo além do campo religioso evangélico. Muitas instituições e autoridades públicas inseridas no campo político - religioso e secular - adotaram essa causa. No campo nacional e no internacional, a linguagem da liberdade religiosa tem se estabelecido como instrumento de legitimidade política, sendo disseminada como valor universal (HURD, 2014, p. 226).

Através dos campos de estudo de Gênero, de Religião e de Relações Internacionais, esse artigo buscou enfatizar a necessidade de discutir as motivações implícitas do discurso aparentemente neutro de defesa da liberdade religiosa. Esse discurso ganha força com o recrudescimento dos conservadorismos na contemporaneidade - reação ao avanço de outras pautas não conservadoras. Nesse contexto, a ideia de liberdade religiosa é redefinida, e esse discurso é instrumentalizado para fortalecer grupos conservadores (não só religiosos) e ir contra direitos de minorias, especialmente de mulheres e pessoas LGBT.

É preciso considerar a eficácia da retórica da liberdade religiosa como estratégia para silenciar o debate político e as vozes que discordam dessa abordagem religiosa de um tema de direitos humanos. O enquadramento desses direitos como derivados de Deus funciona como um argumento de autoridade, onde a discordância é desqualificada de maneira condenatória: quem poderia dizer que é a favor de perseguições religiosas? (CASTELLI, 2007a, p. 685)

Contudo, questionamentos desse tipo são na verdade um desvio do debate. Nenhuma das pesquisas citadas aqui, tampouco este artigo, tem por objetivo desqualificar a liberdade religiosa. O que se discute é a adaptação e a instrumentalização dessa retórica com objetivos que não tem a ver com o objetivo inicial da promoção desse direito. A abordagem religiosa dos direitos humanos traz o risco do esvaziamento do terreno político, pois o argumento de autoridade dado pela interpretação divinizada desses direitos impede o debate, as críticas e a discordância nesses temas.

O projeto de direitos humanos e da defesa da liberdade religiosa tem, dessa forma, se transformado em uma ferramenta de evangelização disfarçada (uma vez que os tempos atuais não favorecem argumentos de moralidade religiosa, mais sectários, e a universalidade passa a ser a característica legitimadora do discurso). Nesse contexto, a situação das pessoase dos grupos cuja visão de mundo não compartilhe dos valores conservadores ou tradicionais precisa ser considerada e discutida com urgência (CASTELLI, 2007a, p. 685).

O discurso contemporâneo pela liberdade religiosa está longe de ser pacífico e unificador. O ecumenismo em torno dele é de conveniência, entre atores religiosos que 
buscam objetivos próprios. Na prática, as diferenças (religiosas ou não) são salientadas nessa abordagem. Marie Gayte (2016, p. 88) alerta que a estratégia de redefinir o conceito de liberdade religiosa com o objetivo de minar os direitos das minorias pode representar um novo começo de guerras culturais nos Estados Unidos, com uma postura belicosa que demanda "desobediência civil" e mesmo enfrentamentos físicos diante de possíveis fracassos dos objetivos conservadores.

A polarização social nos Estados Unidos serve como exemplo didático e um alerta: não é difícil perceber em outras regiões, como o Brasil, que o recrudescimento dos conservadorismos e a apropriação da linguagem de defesa da liberdade religiosa podem trazer riscos ao campo político e social - onde os direitos das mulheres e das pessoas LGBT parecem ser os alvos recorrentes dessa empreitada.

\section{Referências bibliográficas}

CASTELLI, Elizabeth A. Theologizing Human Rights: Christian Activism and the Limits of Religious Freedom. In: FEHER, Michel; GAËLLE, Krikorian; MCKEE, Yates (ed). NonGovernmental Politics. New York: Zone Books, 2007a. Disponível em $<$ https://www.academia.edu/1863006/Theologizing_Human_Rights_Christian_Activism_and the_Limits_of_Religious_Freedom>.Acesso em jul. 2018.

- Persecution complex: identity politics and the "waronchristians".Differences: $a$ journal of feminist cultural studies. v.18, n. 3, 2007b. p. $152-180$. Disponível em $<$ https://www.academia.edu/1862809/Persecution_Complexes_Identity_Politics_and_the_Wa r_on_Christians_>. Acesso em jul. 2018.

. Praying for the Persecuted Church: US Christian Activism in the Global Arena. Journal of Human Rights. v. 4, issue 3, 2005. p. 321 - 351. Disponível em $<$ https://www.academia.edu/1862799/Praying_for_the_Persecuted_Church_US_Christian_Ac tivism_in_the_Global_Arena>. Acesso em jul. 2018.

GAYTE, Marie. La liberte religieuse contre lês femmes et lês homosexuels. Estudos de Religião, v. 30, n. 1 • 75-91 • jan.-abr. 2016

HURD, Elizabeth Shakman. The international politics of religious freedom. IIC Quarterly. Winter-Spring 2014. p. 225-237.Disponível em <http://politics- of-religiousfreedom.berkeley.edu/files/2016/02/15_IIC_Hurd.pdf $>$. Acesso em jul. 2018. 


\title{
Moral e ética cristã: consequências para a constituição da identidade feminina na igreja Assembleia de Deus - Missões
}

Moral and Christian ethics: consequences for the constitution of the feminine identity in the church Assembleia de Deus - Missões

\author{
Ana Luíza Gouvêa Neto ${ }^{37}$ \\ analu172@hotmail.com
}

Resumo: O presente texto faz parte da pesquisa de doutoramento que tem como campo a igreja Assembleia de Deus - Missões, situada na cidade de Juiz de Fora - MG. As páginas a seguir terão como objetivo demonstrar a maneira pela qual igreja vem significando os conceitos de moral e ética cristã e as possíveis consequências para a construção da identidade feminina no interior do espaço religioso. Para tanto, a revista Lições Bíblicas utilizada nas classes de Escola Dominical será analisada, bem como o questionário quantitativo distribuído pela pesquisadora às mulheres assembleinas.

Palavras-Chave: Assembleia de Deus. Feminino. Moral Cristã. Ética Cristã.

Abstract: This text is part of the doctoral research that has as a field the church Assembleia de Deus - Missões, located in the city of Juiz de Fora - MG. The following pages will aim to demonstrate the way in which the church has come to mean the concepts of moral and Christian ethics and the possible consequences for the construction of the feminine identity within the religious space. To do so, the Lições Bíblicas magazine used in the Escola Dominical classes will be analyzed, as well as the quantitative questionnaire distributed by the researcher to the assembly women.

Key Words: Assembly of God. Female. Moral Christian. Christian Ethics.

\section{Introdução}

No intuito de desvelar não somente o discurso oficial produzido e reproduzido pela igreja Assembleia de Deus - Missões, bem como a identidade feminina assembleiana a fim de perceber as possíveis fissuras entre discurso e agencia feminina abordar-se-ão no texto os valores morais defendidos pela igreja. Ademais o texto trará as respostas dadas pelas mulheres ao questionário distribuído no Círculo de Oração. Será possível perceber identidades femininas distintas? Será possível que a normatização da igreja seja a única responsável pela formação identitária feminina?

Desse modo, em primeiro momento serão trabalhadas a "moral e a ética cristã". Fundamental para a compreensão de como as normatizações são engendradas no interior do campo religioso e contribuem para a formação de um habitus especifico àquele campo. Desse

\footnotetext{
${ }^{37}$ Doutoranda em Ciência da Religião pelo Departamento de Pós-Graduação em Ciência da Religião da Universidade Federal de Juiz de Fora. Membro do grupo de pesquisa REDUGE.
} 
modo, a investigação das "regras" da igreja a partir de um olhar de dentro torna-se preponderante. Assim sendo, os conceitos de "moral e ética cristã" serão trabalhados a partir das Lições Bíblicas (20018) utilizadas para as aulas da Escola Dominical. A partir da concepção das regulamentações religiosas os questionários respondidos pelas mulheres serão analisados. Suas respostas estão em confluência com o discurso religioso? Todas as mulheres responderam o questionário de forma semelhante? Caso as mulheres tenham respondido de forma semelhante, é provável que os intentos reguladores da igreja estejam agindo com 100\% de eficácia. Entretanto, se houver diferenciação nas respostas dadas por essas mulheres, infere-se que as mesmas tenham suas identidades constituídas de maneiras distintas, plurais, contingente. Nesse sentido, essas mulheres, assembleianas, estariam performatizando seus gêneros de modos distintos?

\section{Moral e ética cristã: "enfrentando as questões morais de nosso tempo"}

Pretende-se, trabalhar gênero enquanto uma categoria analítica fluída, ou seja, não fixa e estanque. Para tanto, empregar os conceito de habitus e campos inseridos na obra de Pierre Bourdieu, bem como os conceitos de corpo, norma e performatividade encontrados no escritos de Judith Butler se mostram essenciais ao permitirem trabalhar a constituição das identidades religiosas de forma dinâmica. Contudo, seria possível trabalhar a constituição da identidade feminina no interior da Assembleia de Deus - Missões sem ao menos esboçar os valores morais e éticos produzidos e reproduzidos no interior desse espaço religioso? A pesquisadora julga não ser possível, uma vez que os valores morais e a ética cristã compõem boa parte da constituição da identidade do sujeito assembleiano.

Em algumas situações a realização das entrevistas ${ }^{38} \mathrm{com}_{\text {as }}$ mulheres assembleianas se mostraram mais produtivas do que a pesquisadora imaginava que seria. Em certa ocasião, a entrevistada, frequentadora do Círculo de Oração, também lecionava na Escola Dominical, e para a agradável surpresa da pesquisadora as Lições Bíblicas do trimestre referiam-se aos valores cristãos. Resumindo para você leitxr, tal revista se encontra em posse de quem vos escreve e é a partir da revista da Escola Dominical que os valores morais e éticos cristãos serão abordados nas próximas linhas.

\footnotetext{
${ }^{38}$ Por se tratar de um artigo acadêmico não haverá espaço para trabalhar as entrevistas de maneira sistemática.
} 
A revista Lições Bíblicas (2018) é uma publicação trimensal, publicada pela CPAD, dividida em dois volumes: um para xs alunxs e outro volume para xs professorxs. Cada revista, dividida em treze lições, conta com recursos visuais e tecnológicos. O periódico em posse da pesquisadora trouxe as seguintes lições: o que é ética cristã, ética cristã e ideologia de gênero, ética cristã e Direitos Humanos, ética cristã e aborto, ética cristã, pena de morte e eutanásia, ética cristã e suicídio, ética cristã e doação de órgãos, ética cristã e sexualidade, ética cristã e planejamento familiar, ética cristã e vida financeira, ética cristã, vícios e jogos, ética cristã e política e ética cristã e redes sociais. Como se pôde perceber, muitos dos temas trabalhados no periódico em questão são assuntos polêmicos e que têm trazido um caloroso debate na arena pública brasileira.

Assuntos tais como, gênero, aborto e sexualidade ganham as manchetes periodicamente através de debates marcados por uma forte oposição. De um lado, encontra-se uma parcela da população menos conservadora, enquanto do outro lado, encontra-se uma parcela da população que carrega em sua identidade valores cristão. Mas afinal, quais seriam esses valores? De qual forma a moral e a ética cristã se relacionam com temas modernos? Tais perguntas servem como pano de fundo para compreender de qual forma as mulheres assembleianas têm construído suas identidades.

Com base no pensamento de Karl Marx, a moral pode ser entendida como valores que derivam de uma estrutura social. Tais valores, configurados a partir de instituições e agentes detentores de capital simbólico, seriam pensados e colocados em prática a fim de garantir que a estrutura vigente se mantenha. Pensar de acordo com Marx implica pensar que o espaço religioso busca normatizar seu rebanho a fim de perpetuar a estrutura hierárquica no campo, imprimindo um habitus em conformidade com a leitura literalista da Bíblia. Contudo, moral e ética apesar de serem utilizadas enquanto sinônimos em muitos casos, não guardam o mesmo significado. A ética, portanto estaria ligada ao exercício reflexivo acerca do agir do humano, quer dizer, estaria ligada aos critérios normativos na avaliação do comportamento do indivíduo. Ora, mas o que a igreja Assembleia de Deus - Missões estaria entendendo por moral e ética, mas sobretudo, por moral e ética cristãs?

Já na primeira página da revista o texto traz como verdade prática: "As Escrituras Sagradas ensinam o que convêm à virtude do bem-viver cristão em sociedade" (Lições Bíblicas, 2018, p. 03). Ou seja, em primeiro momento a revista busca marcar seu local de fala, a Bíblia. Não obstante, para leitura diária traz a seguinte passagem para as terças-feiras: "A 
palavra de Deus é o fundamento da Ética Cristã’39. Desse modo, antes de entrar na lição, o articulista Douglas Baptista, deixa claro o objetivo do texto: incutir nx leitxr a moral e a ética cristã a partir única e exclusivamente da palavra de Deus. Somente a leitura atenta à Bíblia seria capaz de fornecer as condutas, modos de agir e de ser do sujeito religioso.

Como objetivo geral a lição traz: “Apresentar o conceito e os fundamentos da Ética Cristã” (Lições Bíblicas, 2018, p. 04). A partir desse ponto, traz o conceito da ética cristã, os conceitos de ética e moral, os princípios da ética cristã. Mas, sobretudo, os fundamentos da ética cristã. De acordo com a revista, a ética cristã teria como objetivo a conduta ideal para o ser cristão. Quer dizer, o próprio texto carrega a palavra ideal. Mas pensar em um tipo ideal de sujeito, sobretudo, o sujeito mulher, acarretaria algumas problematizações. Entre elas, a unidade estável da identidade mulher, desconsiderando os vários espaços de sociabilidade pelos quais cada mulher frequentadora da igreja transita.

Ainda com base na revista, a conduta ideal de cada cristão teria como fundamento as virtudes do reino de Deus, ou seja, seriam pautadas nas Escrituras Sagradas sendo indissociáveis das mesmas, na qual, os princípios ético-cristãos seriam imutáveis e obviamente, divinos. Chama atenção a seguinte passagem:

Esses princípios têm aplicação adequada para todas as épocas e culturas, pois são universais. Assim os padrões ético-cristãos não podem ser relativizados: 'o céu e a terra passarão, as minhas palavras hão de ficar'(MT 24.35). [Grifo da autora]. (Lições Bíblicas, 2018, p. 06).

Ora, a passagem acima evidencia a forma pela qual a igreja Assembleia de Deus Missões pretende normatizar e padronizar os sujeitos que transitam no interior de seu espaço religioso. Ao abordar os princípios ético-cristãos enquanto universais, a igreja escamoteia toda historicidade, contextualidade e agência de cada sujeito na formação de sua própria identidade. A partir desse principio, todo sujeito cristão teria sua formação identitária de forma semelhante. Entretanto, as mulheres assembleianas guardam diferenças entre si, tais mulheres, portanto não seriam cristãs? Para além, se você leu atentamente o que foi escrito até aqui, estará se perguntando: a igreja enquanto instituição produtora de capital simbólico estaria se valendo de seu lócus de poder para engendrar nxs fieis um habitus capaz de manter a hegemonia de classificação e organização pautada na diferenciação biológico-sexual? Sim e não.

Sim, pois sendo possuidora de poder, a igreja, ao ser analisada através de um lastro histórico de longa duração tem produzido e reproduzido esquemas de classificação a fim de

\footnotetext{
39 “O céu e a terra passarão, mas as minhas palavras não hão de passar” (Mt., 24:35).
} 
perpetuar a ordem social vigente. A Bíblia - esquema regulatório - que vem sendo utilizada pela instituição religiosa enquanto instrumento de legitimação na distribuição desigual de poder entre os sexos - pautados no binarismo sexual, macho/fêmea - é a única fonte de verdade para a salvação. Desse modo, a instituição religiosa através de seus discursos impressos, audiovisuais, visuais - tem reforçado um padrão conservador e normatizador, consequentemente, excludente em seus adeptos. Mas no frigir dos ovos, os discursos religiosos conservadores têm sido eficazes? Importa para a Tese, identificar os discursos normatizadores de um "feminino ideal", como dito na revista, e a repercussão de tais discursos nas identidades femininas. Parece que na prática tais discursos vêm sendo rearranjados e reinterpretados pelas mulheres assembleianas.

Retomando a resposta negativa dada a pergunta feita em parágrafo anterior, pode-se dizer que a igreja não construa todos seus discursos de maneira maquiavélica a fim de sobrepujar a mulher em detrimento do homem. Apesar, de reforçar certo comportamento patriarcal e heteronormativo, cabe à pesquisadora relativizar os estados da pesquisa. De acordo com Bourdieu (2011) a dominação masculina, construída por vias puramente simbólicas, e aqui indo adiante, discursivas também, insere-se nas coisas e corpos, tanto de dominados como de dominantes. Isto é, a ordem masculina que vem sendo reproduzida de maneira continua ao longo do tempo, ao assumir a característica de natural produz não somente a hierarquia entre os sexos, mas uma hierarquia de poder, que no espaço religioso se reveste de uma moral cristã. Algumas questões podem ser subtraídas desse esquema de pensamento: em primeiro lugar, a reprodução das diferenças com base na anatomia dos corpos masculino/feminino tem sido produzida e reproduzida ao longo de tanto tempo que a essência naturalista já se encontra fortemente demarcada; um segundo ponto a assumir, seria a Bíblia, livro sagrado para xs cristãos, que traria em suas páginas as verdades divinas; um terceiro ponto que chama atenção seria que a distribuição do poder no interior do espaço religioso não ocorre apenas no sentido homem-mulher, mas também, no sentido homemhomem. O que se pretendeu, portanto, ao relativizar a resposta dada a pergunta foi demonstrar que tanto dominantes quanto dominados têm seus corpos e identidades atuando no interior de regimes de poder, os quais, de acordo com o campo têm suas próprias normas e regras, gerando suas matrizes de inteligibilidade, leia-se, matriz moral quando se trata do espaço religioso.

Contudo, percebe-se, agora, que ao introduzir os conceitos de moral e ética cristã, ainda não foi possível deixar claro os intentos para o objetivo do trabalho. Tendo em vista que o trabalho tem por base trabalhar as relações entre gênero - através das mulheres 
assembleianas - e, religião - através da igreja Assembleia de Deus-Missões - julga-se oportuno utilizar a lição dois da revista Lições Bíblicas ao passo que a mesma trabalha "ética Cristã e a Ideologia de gênero". A lição traz como verdade prática os seguintes dizeres: “A doutrina da criação do ser humano revelada nas Escrituras Sagradas, em que a distinção dos sexos é o padrão, não pode ser relativizada." (Lições Bíblicas, 2018, p. 10). Seguindo esse raciocínio, a revista traz a preocupação em relação a "ideologia de gênero" na educação. De acordo com o periódico a "ideologia de gênero" seria:

\begin{abstract}
A palavra "gênero" tem origem no grego genos e significa "raça". Na concepção da lógica, o termo indica "espécie". Usualmente deveria indicar o "masculino" e o "feminino", como ocorre na Gramática. Nesse sentido, a expressão é inofensiva; porém, na sociedade pós-moderna tal significado é relativizado e distorcido em "ideologia de gênero". Essa ideologia também conhecida como "ausência de sexo". Esse conceito ignora a natureza e os fatos biológicos, alegando que o ser humano nasce sexualmente neutro. Os ideólogos afirmam que os gêneros - masculino e feminino - são construções histórico-culturais impostas pela sociedade. (Lições Bíblicas, 2018, p. 12).
\end{abstract}

O trecho acima é sintomático da perspectiva do que a igreja entende como gênero, sexo, sexualidade, orientação sexual. Com bases teóricas fundamentadas nas discussões que envolveram o PNE (Plano Nacional de Educação), em 2014, a Assembléia de Deus age em conformidade no que diz respeito ao conceito e a aplicação do conceito de "gênero" de acordo com a parte religiosa que compõe o Congresso Nacional. Ao criar o termo "ideologia de gênero" o que se viu na arena política foi uma postura conservadora pautada no binarismo sexual para compreensão da identidade sexuada do sujeito. Seguindo tais premissas, a “ideologia de gênero" seria responsável pela troca de papeis entre homens e mulheres, confusão de identidade para o ser humano, desvalorização do casamento e da família.

Obviamente, você, leitrxr atentx, consegue perceber as disfunções entre o que uma perspectiva fluída acerca de gênero, que dê conta de explicar os corpos inteligíveis e ininteligíveis, no interior de uma matriz de inteligibilidade suportada por normas e regras, e desse ponto de vista excludente, e a concepção do que seria a "ideologia de gênero". Ora, torna-se complicado, nesse ponto, manter-se acadêmica. Entretanto, essa perspectiva disfuncional sobre gênero ajudará a compreender não somente os discursos reproduzidos no interior da igreja sobre o que seria próprio ao homem e a mulher, como também colocar em reflexão as mulheres assembleianas que ao transitarem entre vários campos reguladores, estão constituindo um habitus plural, capaz de inseri-las, muitas vezes, de maneira ininteligível no interior da matriz moral religiosa. Portanto, a análise dos questionários quantitativos 
possibilitará perceber que, e aqui, adiantando um pouco os resultados, existe tensão entre os discursos oficiais assembleianos e autorrepresentação de mulher.

\section{A moral cristã se traduz em condutas ideais?}

O Círculo de Oração Rosa de Saron com ocorrência todas as quartas-feiras, com duração entre $08 \mathrm{~h} 00$ às $16 \mathrm{~h} 00$, é um espaço aberto. Nesse sentido, qualquer pessoa pode participar das reuniões, homens, mulheres, crianças, crentes, não crentes, etc. consequentemente, as reuniões se tornam dinâmicas, pois, nem todas as pessoas que estiveram presentes no horário matutino na reunião, estarão presentes no horário vespertino. Não obstante, as pessoas que frequentaram o Círculo de Oração em determinada quarta-feira, nem sempre estarão presentes nos próximos encontros. Isso quer dizer, que fora as dirigentes do Departamento, todas as reuniões são compostas por pessoas diferentes. Tal característica das reuniões implicou em algumas consequências, entre elas: 1. a observação da variação de pessoas que procuram a igreja, particularmente, o Círculo de Oração, na expectativa de sanar algum problema pontual em sua vida; 2 . a dificuldade que a pesquisadora teve em que as mulheres que frequentam o Círculo de Oração preenchessem o questionário proposto.

Dessa forma, foram impressos trinta formulários contendo as seguintes perguntas: 1. Nome, 2. Estado Civil, 3. Profissão, 4. Grau de instrução, 5. Curso, 6. Já trabalhou em quais Departamentos da igreja, 7. Já dirigiu Congregação, 8. Já encontrou alguma dificuldade para exercer alguma tarefa na igreja pelo fato de ser mulher, 9. Gostaria de assumir algum cargo na igreja, 10. aprova o pastorado feminino. Entre as dez perguntas, as de número oito, nova e dez, foram pedidas justificativas das respostas dadas. Resta salientar alguns pontos: ao distribuir os questionários foi informado que as mulheres poderiam preenchê-los de forma anônima, ou seja, sem colocar seus nomes e que, mesmo as que preenchessem seus nomes, suas identidades seriam mantidas anônimas na pesquisa.

Embora informadas que poderiam preencher o questionário de maneira anônima, somente dezoito mulheres se dispuserem a preenchê-lo, ou seja, $60 \%$ apenas. Mas, o que significaria esse número tão pequeno? Tais mulheres estariam envergonhadas de preencher o questionário, ainda com a possibilidade de anonimato? Ou estariam essas mulheres apreensivas a cerca das perguntas contidas no questionário?

Foi pedido que as mulheres preenchessem o questionário, somente ao fim da pesquisa, ou seja, após quatro anos que a pesquisadora frequentava o Círculo de Oração Rosa de Saron. 
Consequentemente, tanto as dirigentes do Círculo, quanto as mulheres mais assíduas já conheciam a pesquisadora e o tema da pesquisa realizada, ainda que de forma, superficial. Acredita-se, portanto, que o baixo número de adeptas que se dispuseram a preencher o formulário relaciona-se ao teor da pesquisa realizada, mas também, ao dinamismo do grupo. Pois, ainda que de maneira sutil, o questionário trazia como marca a discussão sobre gênero. Melhor dizendo, de qual forma os papeis sexuais eram compreendidos por essas mulheres. Bom, com base nas Lições Bíblicas (2018), bem como nos discursos oficiais da igreja, esperava-se que as respostas dadas ao questionário apontassem para uma direção. Mas qual direção seria?

A direção seria óbvia, caso houvesse conformidade entre os discursos oficiais da igreja e a autorrepresentação feminina. As respostas seriam baseadas em uma leitura literalista da Bíblia, pautada na diferenciação sexual biológica entre macho/fêmea. Contudo, as respostas dadas ás perguntas foram sistematizadas e serão apresentadas na tabela a seguir:

Tabela 13. Respostas dadas ao questionário ${ }^{40}$

\begin{tabular}{|c|c|c|c|c|}
\hline \multicolumn{5}{|c|}{ Respostas ao questionário } \\
\hline \multirow{2}{*}{ Nome } & \multicolumn{3}{|c|}{ Preencheu } & Não preencheu \\
\hline & & 11 & & 7 \\
\hline \multirow{2}{*}{ Estado Civil } & Casada & Solteira & Viúva & Não preencheu \\
\hline & 11 & 2 & 3 & 2 \\
\hline \multirow{2}{*}{ Grau de Instrução } & $1^{\circ} \mathrm{grau}$ & $2^{\circ} \mathrm{grau}$ & $3^{\circ} \mathrm{grau}$ & Não preencheu \\
\hline & 7 & 5 & 4 & 2 \\
\hline \multirow{2}{*}{ Trabalhou Departamento } & Sim & Não & & Não preencheu \\
\hline & 15 & 1 & & 2 \\
\hline \multirow{2}{*}{ Dirigiu Congregação } & Sim & Não & Junto ao esposo & Não preencheu \\
\hline & 2 & 15 & 1 & 0 \\
\hline \multirow{2}{*}{ Dificuldade de exercer tarefa } & Sim & Não & & Não preencheu \\
\hline & 2 & 16 & & 0 \\
\hline \multirow{2}{*}{ Gostaria de assumir cargo } & Sim & Não & & Não preencheu \\
\hline & 6 & 8 & & 4 \\
\hline \multirow{2}{*}{ Aprova o pastorado Feminino } & Sim & Não & & Não preencheu \\
\hline & 11 & 6 & & 1 \\
\hline
\end{tabular}

Como visto na tabela acima, entre as dezoito mulheres que preencheram o questionário, sete preferiram manter suas identidades em anonimato. Apenas quatro mulheres, o que representa $25 \%$ das respostas preenchidas cursaram ensino superior. Verificou-se que a maior parte das mulheres trabalhou em algum Departamento da igreja ao longo de sua

\footnotetext{
${ }^{40}$ Tabela criada pela pesquisadora com base nos questionários respondidos por algumas mulheres frequentadoras do Círculo de Oração Rosa de Saron.
} 
trajetória religiosa, e que apenas duas mulheres dirigiram congregações, independente da figura masculina. Sobre as duas mulheres que dirigiram, ou dirigem congregações, salientamse alguns pontos: Leonor ${ }^{41}$ é uma delas, e suas respostas merecem destaques, que serão trabalhadas adiante; a outra resposta positiva para dirigente de Congregação, a pesquisadora julga que tenha sido preenchida de maneira incorreta. Pois, através da resposta da fiel percebe-se que a mesma entendeu como direção de Congregação a coordenação do Círculo de Oração. Entretanto, a resposta na tabela aparece tal como foi preenchida. Não obstante, ainda justificando a desconfiança da pesquisadora, nas conversas e entrevistas realizadas, apenas, duas mulheres foram destacadas enquanto dirigentes de Congregações, Leonor e Darci. Darci, entretanto, não mais dirige Congregação e, por frequentar outra igreja, não fez parte da pesquisa quantitativa e qualitativa.

Ainda sobre os dados trazidos pela tabela, entre as dezoito mulheres, $100 \%$ preencheu sobre a dificuldade de exercer alguma tarefa na igreja pelo fato de ser mulher, e não surpreendentemente, $88,88 \%$ responderam nunca ter encontrado dificuldade em exercer tarefa no interior do espaço religioso. Novamente acredita-se ter havido confusão no preenchimento do questionário: uma das afirmativas positivas foi justificada com a seguinte resposta "Nas igrejas não existe este tipo de problema" ${ }^{~}$. Ou seja, acredita-se que na hora de preencher o questionário a fiel tenha marcado a alternativa "sim" enquanto queria marcar a alternativa "não". Contudo, novamente, a resposta dada ao questionário foi inserida na tabela. Ao ler os questionários e perceber que apenas uma mulher disse, de fato, ter encontrado dificuldade em exercer cargo na igreja por consequência de seu gênero, a pesquisadora foi atrás da fiel para tentar uma entrevista. Ora, entre dezoito mulheres, ser a única a afirmar algo, significaria alguma coisa, foi o que a pesquisadora pensou.

Voltando as informações contidas na tabela, sobre assunção de cargos no interior do espaço religioso, oito mulheres entre quatorze respostas preenchidas, melhor dizendo, $57,14 \%$ afirmaram não ter interesse em preencher algum cargo na igreja. As respostas vão ao encontro da pregação de uma "irmã" em uma reunião ocorrida em 2018 do Círculo de Oração. Vai ao encontro de qual forma? Na pregação, a fiel afirmou que muitas vezes as mulheres "não dão as caras a tapa", ou seja, muitas mulheres, nessa perspectiva, não teriam coragem em assumir a lideranças de suas igrejas, ou mesmo assumir mais responsabilidade no espaço religioso. Desse modo, as mulheres, a partir dessa fala, estariam abrindo mão de um espaço permitido a elas. Contudo, as mulheres estariam de fato abrindo mão de espaços concedidos a elas? $\mathrm{Ou}$

\footnotetext{
${ }^{41}$ Os nomes utilizados no artigo são fictícios com a finalidade de preservar a identidade dos interlocutores.

${ }^{42}$ Questionário $n^{\circ} 13$, respondido por uma frequentadora do Círculo de Oração Rosa de Saron.
} 
estariam essas mulheres agindo de acordo com o habitus religioso? Ora, parece que parte das mulheres, maioria, nesse caso, estaria agindo conforme a lógica religiosa no interior do campo. De acordo com Bandini "a autoridade religiosa feminina será fortalecida pela associação entre os papeis da maternidade e da cuidadora do lar" (Bandini, 2014, p. 60). Quer dizer, a identidade feminina no interior do espaço religioso, regulado por sua própria matriz de inteligibilidade - moral e ética - não perpassaria pela mulher enquanto líder religiosa, mas enquanto, mãe e auxiliadora. Ainda assim, seis mulheres responderam ter interesse na assunção de cargos no interior do espaço religioso. Ta afirmação representaria uma tensão entre o discurso oficial e a autorrepresentação feminina? A resposta para tal pergunta dependeria dos tipos de cargos aspirados por essas mulheres.

Entre as que especificaram suas respostas, aspiram cargos que trabalhem com crianças e com louvor. Não obstante, os cargos que apareceram enquanto já desempenhados por essas mulheres em algum momento de suas histórias religiosas são relacionados à oração, à missão, ao cuidado infantil, ao coral, a Escola Dominical e, uma exceção: trabalho na tesouraria, exercido por Rita. Tanto as respostas dadas aos cargos aspirados quanto aos já ocupados em algum momento, salvo o cargo de tesoureira exercido por Rita, simbolizam a normatização sofrida pelas mulheres no interior da igreja. Mas o que significaria essa normatização?

Mais de 50\% das mulheres não têm interesse em avocar para si um cargo religioso, entre as seis que gostariam de um cargo, os dois são relacionados ao que se pretende e espera para a mulher cristã. O que se verifica, portanto, é o forte caráter regulador da igreja na identidade feminina, trazendo consequências para o modo de agir e pensar. Empreende-se que apesar das mulheres assembleianas apresentarem identidades plurais, uma vez que algumas pretendem cargos, enquanto outras não, o poder no interior do espaço religioso age de forma a naturalizar e essencializar (Butler, 2002, p. 64) esse corpo feminino, consequentemente, sua identidade sexuada, ou melhor, o habitus sexuado. Consequentemente o esquema hegemônico de classificação - binário sexual - parece operar com eficácia no interior da Assembleia de Deus - Missões. Embora tal esquema dite as regras e as normas inteligíveis e ininteligíveis, sua eficácia não é de $100 \%$. Mas como se pode analisar a eficácia do sistema regulador assembleiano?

O questionário através de suas repostas traz pistas para a compreensão da eficácia do poder normatizador, regulador, consequentemente, excludente, no campo. Mas, sobretudo, as respostas dadas a última pergunta do questionário, ilustram de forma significativa a resistência das mulheres a um discurso normatizador excludente, usualmente utilizado para sobrepujar o feminino em detrimento do masculino. 
Entre as dezoito mulheres, apenas uma mulher não preencheu a pergunta final do questionário: "Aprova o pastorado feminino? Sim ( ) Não ( ). Justifique sua resposta:"43. Entre as dezessete que preencheram, 11 mulheres afirmaram aprovar o pastorado feminino, o que significa que $64,7 \%$ das mulheres aprovam o pastorado feminino, em contrapartida, as seis que desaprovam o pastorado feminino representam $35,29 \%$. A diferença entre apoiadoras do pastorado feminino e as que desaprovam o pastorado feminino é praticamente o dobro. $\mathrm{E}$ aqui, insere-se o ponto nevrálgico da pesquisa, o qual seria o limiar para a aplicabilidade da teoria da performatividade de gênero à luz de Judith Butler.

De acordo com Butler (2018, p. 09) o poder opera de maneira discursiva, o que significaria que o mesmo só poderia ocorrer e ser exercido no interior de relações sociais, nesse caso especificamente, no campo formado pela Assembleia de Deus - Missões. Não obstante, a produção e reprodução de padrões de gênero estariam ligadas às relações de poder que trabalham no interior de espaços de sociabilidade com fim último de normatizar certas variações de sujeito em detrimento de outras. E, no espaço religioso, a Bíblia seria um esquema regulatório instrumentalizado a fim de tornar as mulheres inelegíveis a certos postos no interior da igreja (Butler, 2018, p. 57). Nesse sentido, o poder institucional, perpetrado nas coisas e nos corpos afetariam os sujeitos de maneira a modelar os discursos sobre gênero, sexo, sexualidade, etc. a fim de originar e propagar tipos ideais de gênero, sexo, sexualidade, caracterizando-os enquanto ontológicos. Dotados de essências naturais, verdades interiores, universais e a-históricos.

Contudo, às vezes a regulação, as normas - leia-se o poder - não agem em conformidade com o pretendido, ocasionando de dentro da matriz de inteligibilidade, formas de resistência, de tensão e reorientação da regulação imposta no interior de determinado campo. Butler (2018, p. 32) afirma que "os corpos em assembleia dizem: "nós não somos descartáveis"”, mas como diriam os corpos não reunidos? Os corpos femininos assembleianos estariam resistindo à norma? Se sim, de qual maneira tais corpos estariam dizendo "também podemos liderar!"? Para além, o Círculo de Oração poderia ser compreendido enquanto um espaço no qual os corpos estão reunidos?

$\mathrm{O}$ insight para trabalhar a mulher assembleiana enquanto sujeito estaria centrado na construção da identidade de cada ser humano. De maneira a pensar a constituição da identidade feminina assembleiana perpassada por inúmeras especificidades: classe, raça, escolaridade, localidade, idade, etc. a fim de perceber que toda identidade é constituída a

\footnotetext{
${ }^{43}$ Questionário feito pela pesquisadora para que as mulheres frequentadoras do Círculo de Oração Rosa de Saron preenchessem. 2018.
} 
partir da pluralidade. Desse modo, o campo que compõe a Assembleia de Deus - Missões, com suas normas e regras, constituem, sim uma matriz de inteligibilidade que age na formação de um habitus sexuado. Contudo, em consequência de uma contextualização, historização é possível perceber compreensões de feminino distintas entre as mulheres que responderam o questionário. Pois, ao responderam que aprovam o pastorado feminino, as onzes mulheres assembleianas, estão rompendo as barreiras da norma religiosa, legitimada e fundamentada na palavra bíblica.

Bom, rompem-se as barreiras teológicas na teoria, mas na prática essas mulheres estariam reproduzindo a frase pega por empréstimo de Butler? - 'nós não somos descartáveis' (Butler, 2018, p. 32). No momento, propõe-se um retorno rápido as justificativas negativas ao pastorado feminino.

Entre as justificativas negativas em relação ao pastorado feminino encontram-se as seguintes respostas: "Pelo fato de se enfrentar certas situações que requer a atuação de um pastor (homem). Não que a mulher não tenha capacidade de exercer o ofício" [sic] $]^{44}$, "Não encontro base bíblica para tal" 45 " "Não porque na Bíblia encontramos base para pastora e sim auxiliar do trabalho" [sic] ${ }^{46}$, "A Palavra de Deus responde na minha Bíblia não tem pastora" $[\mathrm{sic}]^{47}$. Entre as quatro justificativas para a desaprovação do pastorado feminino, três têm suas respostas baseadas na Bíblia. Trechos como: "E disse o Senhor Deus: Não é bom que o homem esteja só; far-lhe-ei uma adjutora que esteja diante dele" (Gên., 2:18), "E ele mesmo deu uns para apóstolos, e outros para profetas, e outros para evangelistas, e outros pastores e doutores" (Ef., 4:11), que através da observação dos eventos na igreja, das entrevistas realizadas e das conversas tidas ao longos dos quatro anos de pesquisa, usualmente são proferidos por homens a fim de legitimar o homem enquanto pastor e a mulher enquanto adjutora. E embora, seja um discurso conservador para a manutenção do distanciamento da mulher a cargos de poder, verifica-se a reprodução desse discurso patriarcal, heteronormativo através de mulheres assembleianas.

Importa salientar dois pontos: o primeiro referente à justificativa dada presente no questionário de número dois: "Pelo fato de se enfrentar certas situações que requer a atuação de um pastor (homem)" "48. Ora, quais seriam essas situações que necessitariam de um homem? Infelizmente não foi possível perguntar, pois o questionário foi respondido de

\footnotetext{
${ }^{44}$ Questionário $n^{\circ}$ 02, respondido por uma frequentadora do Círculo de Oração Rosa de Saron.

${ }^{45}$ Questionário $\mathrm{n}^{\mathrm{o}}$ 03, respondido por uma frequentadora do Círculo de Oração Rosa de Saron.

${ }^{46}$ Questionário $n^{\circ} 04$, respondido por uma frequentadora do Círculo de Oração Rosa de Saron.

${ }^{47}$ Questionário $n^{\circ} 01$, respondido por uma frequentadora do Círculo de Oração Rosa de Saron.

${ }^{48}$ Questionário $\mathrm{n}^{\mathrm{o}}$ 02, respondido por uma frequentadora do Círculo de Oração Rosa de Saron.
} 
maneira anônima. Defere-se, entretanto, da resposta, que o esquema de classificação hegemônico pautado no binarismo sexual vem operando de maneira eficaz na compreensão do ser mulher para essa fiel. A pesquisadora não consegue pensar, para além de uma função reprodutiva, qual seria a diferença entre situações que necessitassem de homens as quais mulheres não pudessem atuar, pensando de maneira binária, ou seja - reducionista. Entretanto, para a mulher que respondeu tal pergunta fica nítida a concepção que a mesma tem de constituição de sexo e gênero. Consequentemente, depreende-se através da resposta que para essa mulher, homens e mulheres têm papeis sociais distintos que são marcados de forma clara.

O segundo ponto a ser destacado, e talvez, mais intrigante, refere-se à resposta dada ao questionário de número 01. Apesar de ter sido preenchido de maneira anônima, a partir da resposta dada a pergunta relativa à direção de alguma Congregação, pôde-se identificar a identidade da pessoa. Trata-se, portanto, de Leonor. Ora, sua resposta foi clara, e saltou aos olhos da pesquisadora como um grito: "A Palavra de Deus responde na minha Bíblia não tem pastora" $[\mathrm{sic}]^{49}$. Leonor, afora dirigir uma Congregação que compõe o campo da Assembleia de Deus - Missões é fortemente contra o pastorado feminino. Como compreender a identidade sexuada de Leonor? Leonor ao dirigir uma Congregação estaria assumindo o mesmo lócus de poder que um pastor. Desse modo, a concepção de Leonor estaria em conformidade com a afirmação encontrada no questionário de número 02 , a qual se depreendeu que algumas funções seriam próprias a homens e outras a mulheres?

O caso de Leonor é intrigante e simboliza o rasgo às normas contidas e reproduzidas no interior do campo religioso. Ao mesmo tempo, demonstra a efetividade das normas sociabilizadas no seio da Assembleia de Deus - Missões. Deduze-se, portanto, através, não somente, das respostas dadas por Leonor, mas por todas as mulheres que responderam o questionário algumas conclusões: em primeiro lugar, a igreja enquanto instituição tem transmitido suas normas e condutas com base em uma moral e uma ética cristã, em segundo lugar que a constituição das identidades femininas tem sido efetivada não em conformidade com o que a igreja pretende - de maneira unitária, a-histórica e universal - pelo contrário, as respostas são plurais, distintas, ainda que algumas guardem semelhanças, em terceiro lugar, mas não menos importante, as respostas esclarecem que as normas internas a um campo constituem um habitus, nesse caso religioso, mas que a identidade de cada sujeito é formulada através de vários habitus. Sendo assim, pôde-se verificar as normas religiosas agindo com

\footnotetext{
${ }^{49}$ Questionário $n^{\circ}$ 01, respondido por uma frequentadora do Círculo de Oração Rosa de Saron.
} 
certa eficácia no espaço analisado, entretanto, a eficácia encontra um limite, justamente, na formação de uma identidade de gênero constituída de maneira plural.

\section{Considerações}

Após a leitura atenta das linhas trazidas anteriormente, parece ser possível inferir algumas conclusões, ainda que parciais. Destaca-se em primeiro momento a intenção em regular, sobretudo, as mulheres de forma incisiva tentada pela igreja Assembleia de Deus. Através, das revistas analisadas durante a pesquisa de Mestrado (Gouvêa Neto, 2015), notouse a preocupação da Igreja Assembleia de Deus em normatizar os corpos e as condutas das mulheres assembleianas. Mas tal normatização seria, na prática, imposta no interior dos espaços religiosos? Ao acompanhar os cultos, aulas da Escola Dominical, os Congressos realizados na igreja Assembleia de Deus - Missões, situada na cidade de Juiz de Fora, o que se pôde perceber é a continuidade dos intentos pretendidos pelas revistas. As falas do pastorpresidente, em entrevistas e em momentos de festividades vão ao encontro dos ensinamentos trazidos na revista Lições Bíblicas (2018): “os princípios ético-cristãos que derivam das Escrituras são imutáveis e divinos. Esses princípios têm aplicação adequada para todas as épocas e culturas, pois são universais" (Lições Bíblicas, 2018, p. 06). Ora, a igreja enquanto campo de forças tem suas próprias regras, normas e consequentemente cria um habitus em conformidade com uma matriz de inteligibilidade.

Contudo, a partir das respostas fornecidas ao questionário pelas mulheres assembleianas, ainda que de forma inconsciente, essas estão em desacordo com a citação trazida acima. Mas como ter certeza de tal afirmação? Parece óbvio: as mulheres assembleinas estão agindo e performatizando seus gêneros de maneiras "inadequadas", não aceitáveis e esperadas para mulheres cristãs. Quando elas se vestem de maneira diferente do esperado, por exemplo, trajando calças, ou mesmo quando elas assumem a direção de uma igreja, se comportando como pastoras - função essa, proibida para mulheres na Assembleia de Deus - Missões. Viu-se, portanto, que cada mulher tem um ponto de vista diferente da outra.

\section{Referências}

BANDINI, Claudirene. Costurando certo por linhas tortas: práticas femininas em igrejas pentecostais. Salvador: Editora Pontocom Ltda, 2014.

Bíblia, Edição de Promessas. Mateus, 24:35, 2006.

BOURDIEU, Pierre. A dominação masculina. Rio de Janeiro: Bertrand Brasil, 2011.

BUTLER, Judith. Corpos em aliança e política das ruas: notas para uma teoria performativa de assembleia. Rio de Janeiro: Civilização Brasileira, 2018. 
BUTLER, Judith. Cuerpos que importan: sobre lós limites materiales y discursivos del "sexo". Buenos Aires: Paidós, 2002.

GOUVÊA NETO, Ana Luíza Gouvêa. Na capa e por dentro: uma análise sócio histórica sobre a mulher evangélica em publicações assembleianas. 2015. 148f. Dissertação (Mestrado em Ciência da Religião) - Universidade Federal de Juiz de Fora, Juiz de Fora, 2015.

$L I C ̧ O \tilde{O} E S$ BÍBLICAS. Valores Cristãos: enfrentando as questões morais de nosso tempo. Rio de Janeiro: CPAD, abr. - jun., 2018. 